\title{
Millî Şef İsmet İnönü Dönemi Laiklik Uygulamaları
}

\author{
Dr. Ali DİKİCi
}

\begin{abstract}
ÖZET
Türkiye'de Millî Şef İsmet İnönü dönemi özellikle İkinci Dünya Savaşı'nın da

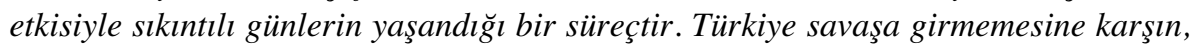
bu süreç, hemen her konuda olduğu gibi ülkenin iç güvenliğini de doğrudan etkilemiştir. Millî Şef yönetimi iç güvenliği sarsacak durumlara gücünü sarf etmeme ve mevcut enerjisini dlş savunmaya yönlendirme düşüncesi ile, iç güvenlikle ilgili en ufak hareketlenmeye bile sert tepki vermiştir. Yönetim, bu endişelerin yanı sira, laikliğin ülkede kökleșmesi için yoğun bir çaba sarfetmiş, Cumhuriyet devrimleri için bir tehdit oluşturabilecek hareketlere karşı tavizsiz bir tutum sergilemiş ve savaşın getirdiği tüm olumsuz şartlara rağmen bu konudaki en küu̧ük oluşumlar bile sıkı takip altına almıştır. Bu konuda güvenlik güçlerine büyük bir sorumluluk düşmüsstür. Bu makalede, Millı̂ Şef döneminde Türkiye'deki laiklik uygulamalarl, devrimlere karşı tehdit oluşturabilecek oluşumlar, faaliyetler ve olaylar, yönetimin bunlar karşısındaki tutumu, Emniyet Genel Müdürlüğü arşivlerinden alınan bilgiler çerçevesinde incelenmeye ve olaylar 'polis ve güvenlik' boyutuyla ele alınmaya çalışılmıştır.
\end{abstract}

Anahtar Kelimeler: Millî Şef, İnönü, Laiklik, Türkçe Ezan, İkinci Dünya Savaşı.

\section{Secularism Practices During the Reign of National Chief (Millî Şef) İsmet İnönü}

\begin{abstract}
The reign of National Chief İsmet İnönü (Millî Şef) in Turkey is a troublesome period particularly due to World War II. Although Turkey did not participate in the War, the country faced many challenges to its homeland security as well as to other
\end{abstract}

*3. Sınıf Emniyet Müdürü, Eskişehir, dikiciali@yahoo.com 
fields. Therefore, authorities dealt not only with minor domestic incidents in order not to use resources that could be required for a possible war and defense and strictly applied the rules and regulations as to security but also the secularism was taken as priority and the activities and the incidents against the Atatürk Reforms were pursued by law enforcement officers very closely in spite of war threat against Turkey. The law enforcement officers worked hard in this period. So, this article concentrates on the activities and the incidents relating the secularism practices, threats against the Atatürk Reforms, and the attitudes of the Turkish governments. In doing so, many documents from the Turkish National Police archives were employed and the events were explored from "police and security" point of views.

Key Words: National Chief (Millî Şef), İnönü, Secularism, Turkish Ezan (call to prayer), Second World War.

\section{GİRİŞ}

Büyük önder Mustafa Kemal Atatürk'ün vefatının ardından İsmet İnönü'nün Cumhurbaşkanı seçilmesiyle Türkiye'de Millî Şef dönemi adı verilen yeni bir dönem başlamıştır. Bu makalede Millî Şef döneminde, laiklik ilkesi çerçevesinde Atatürk devrimlerinin kökleşmesi adına yapılan uygulamalar, polis arşiv kaynaklarından yararlanılarak incelenmiştir. İkinci Dünya Savaşı'nın getirdiği olağanüstü koşullardan dolayı bu dönemde basın üzerinde uygulanan sıkı denetim, ${ }^{1}$ diğer tüm alanlarda olduğu gibi bu dönemin laiklik uygulamalarına dair sağlıklı bilgi edinilmesini de zorlaştırmaktadır. Bu nedenle Millî Şef Dönemi laiklik uygulamalarını inceleyebilmek için kaleme alınan bu makalede, mevcut kaynakların yanı sıra yoğun olarak Emniyet Genel Müdürlüğü arşivlerinde yer alan bilgi ve belgelerden yararlanılmıştır.

Atatürk'ün 10 Kasım 1938'de hayata gözlerini yummasının ardından, 11 Kasım 1938 günü, Cumhuriyet Halk Fırkası Meclis Grubunda yapılan toplantıda; İsmet İnönü Türkiye'nin ikinci Cumhurbaşkanı seçildi. İnönü'nün Cumhurbaşkanlığına seçilmesiyle geriye Cumhuriyet Halk Partisi Genel Başkanlığı seçimi kalmıştı. Bu amaçla 26 Aralık 1938'de Ankara'da toplanan CHP kurultayında, CHP Genel Başkan Vekili Celal Bayar, CHP programının genel başkan seçimiyle ilgili maddesini değiştirmek üzere bir tasarı sundu. Bu tasarıda, Partinin kurucusu ve ebedi Başkanı'nın Türkiye Cumhuriyetinin kurucusu olan Kemal Atatürk olduğunu ve Partinin değişmez Genel Başkanı'nın İsmet İnönü olduğunu ifade ettikten sonra, Partinin değişmez Başkanlığının ancak vefat, vazife yapamayacak hastalık

${ }^{1}$ Cemil Koçak, “İkinci Dünya Savaşı ve Türk Basını”, Tarih ve Toplum, Cilt: VI, Sayı: 35 (Kasım 1986), s. 29; Mete Tunçay, “Tek-Parti Döneminde Basın”, Tarih ve Toplum, Cilt: VII, Say1: 37 (Ocak 1987), s. 48. 
veya istifa halinde boşalabilmesini teklif etti. ${ }^{2}$ Oybirliği ile kabul edilen bu tasarıdan sonra İnönü, yalnız devletin başı olarak değil, tek partili siyasi iktidarın da Değişmez Başkanı ve Millî Şefi olarak ülkedeki bütün yetkileri eline aldı. Böylece İnönü'nün idaresinde tek parti yönetiminin, hayatın her alanında söz sahibi olduğu, politikayı bizzat ve doğrudan doğruya İnönü'nün idare ettiği ${ }^{3}$ bir dönem başladı. Millî Şef Dönemi adı verilen ve İkinci Dünya Savaşı gibi çetin bir süreci de içine alan sekiz yıllık bu "olağanüstü" dönem, 10 Mayıs 1946 tarihinde yapılan, Cumhuriyet Halk Partisi İkinci Olağanüstü kurultayında, İnönü'nün önerisi üzerine, "Değişmez Genel Başkan" ve "Millî Şef" sıfatlarının kaldırılması ${ }^{4}$ ile resmen sona erdi.

Savaş boyunca Türkiye'yi ateş çemberinin dışında tutmayı başaran İnönü, ${ }^{5}$ Atatürk reformlarının kaderini de, Türkiye'deki batılılaşmanın ateşli savunucusu ve bekçisi olacağı şüpheli kişilerin ellerine bırakmamak ${ }^{6}$ için azami gayret göstermiştir. Bu nedenle, Mango'nun belirttiği gibi, İnönü, önceliği , devletin siyasi ve ekonomik bağımsızlığı, ulusal toprakların bütünlüğü, yurtiçindeki kanun ve düzen, Atatürk'ün kültür devrimi ve ulusal ekonominin ağır ama emin adımlarla gelişmesi gibi cumhuriyetin başarılarını korumaya verdi. İ İönü'nün, savaşın en şiddetli olduğu ve Türkiye'nin savaşa girmesinin an meselesi olduğu bir durumda bile bu konuda geri adım atmadığı, devrimlere zarar verebilecek en küçük bir oluşuma bile fırsat vermediği görülmektedir.

Aydemir'e göre Millî Şef'lik Atatürk döneminde başlayan, fakat tamamlanamayan ve hatta çoğu kökleştirilemeyen devrimleri devam ettirmek, kökleştirmek ve derinleşmesini sağlamak için bir yoldu. ${ }^{8}$ Yılmaz'ın da vurguladığı gibi Atatürk ile birlikte Millî Mücadele'yi yürütmüş ve

${ }^{2}$ Cumhuriyet Halk Partisi Üsnomal Büyük Kurultay'ın Zabtl, (26.12.1938), Recep Ulusoğlu Basımevi, Ankara, 1938, s.37. s. 21.

${ }^{3}$ Metin Toker, Tek Partiden Çok Partiye 1944-1950, Milliyet Yayınları, İstanbul, 1970

${ }^{4}$ Cemil Koçak, "Siyasal Tarih (1923-1950)”, içinde Türkiye Tarihi-4, Căğdaş Türkiye: 1908-1980, (ed. Sina Akşin ve diğerleri), Cilt: IV, Cem Yayınevi, İstanbul, 2000, s. 174. Bu dönemi inceleyen birçok eserde Millî Şef dönemi, 1938-1945 yılları arasındaki dönemle sınırlandırmaktadır. Bkz. Mahmut Goloğlu, Millî Sef Dönemi (1939-1945), Kalite Matbaası, Ankara, 1974; Cemil Koçak, Türkiye'de Millî Şef Dönemi (1938-1945), (Dönemin İç ve Dış Politikası Üzerine Bir Araştırma), Yurt Yayınları, Ankara, 1986; Osman Akandere, Millî Şef Dönemi: Çok Partili Hayata Geçişte Rol Oynayan İç ve Dış Tesirler (1938-1945), İz Yayıncılık, İstanbul, 1998.

${ }^{5}$ Metin Toker, a.g.e., s. 21.

${ }^{6}$ Necdet Uğur, Ísmet İnönü, Yapı-Kredi Yayınları, İstanbul, 1995, s. 59. Nitekim 1939 yılında gerçekleştirilen CHP 5. Büyük Kurultayına sunulan ve 4. Büyük Kurultayda kabul edilen parti programının gerçekleştirilen kısımları ilgili raporda, "inkılâp prensiplerinden taviz verilmeden emniyetin sağlandığ ı" vurgulanmıştır. Bkz. C.H.P. Programının Hükümetçe Tahakkuk Ettirilen Kısımları Hakkındaki Rapor, Ulus Matbaası, Ankara, 1939, s. 6.

${ }^{7}$ Andrew Mango, Türkiye ve Türkler: 1938'den Günümüze, Remzi Kitabevi, İstanbul, 2005 , s. 38.

${ }^{8}$ Şevket Süreyya Aydemir, İkinci Adam, Cilt: II, Remzi Kitabevi, İstanbul, 1991, s. 50. 
kazanılan zaferi takiben Atatürk tarafından yeni ve modern bir ulus devleti olma yolunda gerçekleştirilen devrimlerin gerek yapılma gerekse onların toplum tarafindan benimsenmesinde çaba sarfetmiş olan İnönü, Atatürk'ün ölümü sonrasında yine aynı kararlılıkla yeni anlayışın devamı doğrultusunda bir tavır sergilemiştir. ${ }^{9}$ Böylece esas olarak Millî Şef'ten önce başlamış olan ve geniş halk kesimlerini etkileyen laiklik uygulamaları, bu dönemde savaşın getirdiği olumsuzlukların da etkisiyle, tavizsiz bir şekilde devam ettirilmiştir. $\mathrm{Bu}$ amaçla Atatürk reformlarının bazılarını koruyan yasaları çiğneyen kişilere uygulanacak cezalar arttırılmıştır. ${ }^{10}$

\section{Yönetimin Devrim Kanunlarına Aykırı Faaliyetlerle Mücadelesi}

Bu dönemde, eğitimin çağdaş ve laik ölçülerde yapılabilmesi için devlet eliyle gerçekleştirilmesini öngören 3 Mart 1924 tarihli Tevhid-i Tedrisat Kanunu'na ve Arap harflerinin yerine Latin harflerinin kullanılmasını öngören 1 Kasım 1928 tarihli ve 1353 Sayılı Türk Harflerinin Kabul ve Tatbiki Hakkındaki Kanun'a muhalif hareketler, ${ }^{11}$ güvenlik güçlerinin sıkı takibine alınmıştır. Benzer şekilde, 4 Ocak 1932 tarihinde yayınlanan bir talimatnamede; Harf Devrimi Kanunu'na aykırı olarak Arap harfleriyle eğitim yapmak için gizli veya aleni dershane açanların ve bu dershanelerde eğitim verenlerin, Türk Ceza Kanunu'nun 526ıncı maddesi gereğince üç aya kadar hafif hapis veya 10 liradan 200 liraya kadar hafif para cezası ile cezalandırılacağı belirtilmiş ${ }^{12}$ olmasına rağmen, zaman zaman bu kanunlara ve talimatlara aykırı hareket edenler olduğu ve bu kişiler hakkında işlem yapıldığı görülmektedir. Örneğin 1 Kasım 1935 ve 30 Kasım 1936 tarihleri arasında çeşitli illerde 35 kişi gizli bir surette Arap harfleri ile tedrisat yapmak suçundan yakalanıp adliyeye sevk edilmişlerdir. ${ }^{13} 1937$ yılında Gaziantep'te 50 yaşlarındaki bir kadının kendi evinde gizlice eski usül Arap harfleri ile çocuk okuttuğu haber alınmış ve suçüstü yakalanarak, aramada ele geçen kitaplarla birlikte mevcuden mahkemeye sevk edilmiştir. Ele geçen kitaplar ve bazı eşyalar ise şunlardır: 3 adet Mevlüt, 5 Tebareke cüzü, 25 Amme cüzü, 1 Kadesemiallah, 7 Kur'an-1 Kerim, 10 Elif Cüz’ü 2

${ }^{9}$ Mustafa Yılmaz, "Cumhuriyet Döneminde Bakanlar Kurulu Kararı İle Yasaklanan Yayınlar 1923-1945", Kebikec, Yıl: 3, Sav1: 6, 1998, s. 53-80

${ }^{10} \mathrm{Bu}$ konuda, 1941 yilında Şapka Kanununu ihlal edenlere verilecek cezaların artırılması ve Arapça Ezan yasağını çiğneyenlerin cezalandırılması ilgili yasal düzenlemeler örnek olarak verilebilir.

${ }^{11}$ Ancak Türk Harflerinin Kabul ve Tatbiki hakkındaki kanun "eski harflerle basılı kitaplarla tedrisat icrası memnuiyetini muhtevi olup", eski harflerle basılmıș kitapların okul ve kültür kurumlarına, kitabevlerine konulmalarını yasaklamamaktadır. Bkz. Bülent Daver, Türkiye Cumhuriyeti'nde Laiklik, Siyasal Bilgiler Fakültesi Yayınları, Ankara, 1955, s. 230.

${ }_{12}$ Halim Alyot, Türkiye'de Zabıta, Tarihi Gelişim ve Bugünkü Durum, Kanaat Basimevi, Ankara, 1947, s. 937.

13 Emniyet Genel Müdürlü̆̆̈̈ Arşivleri [EGMA, Ankara], D[osya]. 13217-11, K[ardeks]. 1964; Dâhiliye Vekâletinin Maarif Vekâletine yazdığı 12.1.1937 tarih ve 368 sayılı yazi. 
Minder, 1 sıra, 1 sopa. ${ }^{14}$ Benzer şekilde, Arapça namaz sûresi okutmak veya Arapça tedrisatta bulunmak suçundan 1938 yılı içerisinde; Çankırı'da iki gözü kör ${ }^{15}$ birisi, Kastamonu'da bir kadın, ${ }^{16}$ Isparta'da muhtelif şahıslar, ${ }^{17}$

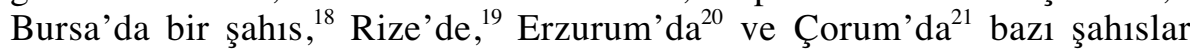
hakkında işlem yapılmıştır.

Millî Şef döneminde de benzer suçları işleyen şahıslar hakkında işlem yapılmaya devam edilmiştir. 1939 yılında Erzurum'un köylerinde ${ }^{22}$ bazı şahıslar yakalanarak adliyeye sevk edilmişlerdir. İçişleri Bakanı, 3üncü Umumi Müfettişliğine gönderdiği bir yazıda, çocuklara Arapça tedrisat yaptıranlarla ilgili olarak "kanunlarımıza ve rejime aykırı olan bu vak'a faillerinin fenalıklarını yerinde bastırmak ve sari mikroplar gibi yurda dağıtmamak başlıca esastır. Binaenaleyh Halk Partisi ve evleri cihazı ile harekete geçilerek bu kötü propagandalar önlemek ve kötüleri adaletin pençesine vermek lazımdır. Bu yoldaki iyi çalışmalarınızı memnuniyetle takip ediyorum."23 sözleriyle görevlileri uyarmıştır.

Ancak bu uyarıya rağmen Arapça tedrisat yaptıran birçok insan yakalanarak adliyeye sevk edilmiştir. Örneğin, Trabzon'da Hıfz muallimi olmadığı halde küçük yaştaki çocukları hıfza çalıştırdıklarından adliyeye sevk edilen İsmail oğlu Mustafa ve arkadaşları beraat etmişlerdir. ${ }^{24}$ Urfa'da dükkânında Arapça harflerle basılmış Elifba, Amme, Tebareke cüzleri satan bir şahıs, ${ }^{25}$ Giresun'da Arapça tedrisat yaptıran şahsın yanı sıra kanuni vazifesini yapmamaktan muhtar ve ihtiyar heyeti üyeleri, ${ }^{26}$ Konya'da bir köy

${ }^{14}$ EGMA. D.13217-3, K.596; Gaziantep Valiliğinin Dâhiliye Vekâletine yazdı̆̆ 31.12.1937 tarih ve 1481 sayll yazı.

${ }^{15}$ EGMA. D.13217-3, K.595; Çankırı Valiliğinden Dâhiliye Vekâletine gönderilen 3.1.1938 tarih ve 21 sayılı yazı.

${ }^{16}$ EGMA. D.13217-5, K.597; Kastamonu Vali Vekili N. A. Keskin imzası ile Dâhiliye Vekâletine gönderilen 10.1.1938 tarih ve Em.1/37 sayılı yazı.

${ }_{17}$ EGMA. D.13217-8, K.906; İsparta Valiliğinden Dâhiliye Vekâletine gönderilen 10.1.1938 tarih ve $26837 / 48$ sayili yazi.

${ }_{18}$ EGMA. D.13217-12, K.287. Bursa Valiliğinden Dâhiliye Vekâletine gönderilen 20.1.1938 tarih ve 175 sayili yazi.

${ }_{19}$ EGMA. D.13217-13, K.3109; Rize Valiliğinden Dâhiliye Vekâletine gönderilen 29.1.1938 tarih ve 1087 sayılı yazı.

${ }^{20}$ EGMA. D.13217-15, K.3118; Dâhiliye Vekâleti Şükrü Kaya imzasıyla Maarif Vekâletine gönderilen 21.2.1938 tarih ve 7872 sayılı yazı.

${ }^{21}$ EGMA. D.13217-14, K.3119; Dâhiliye Vekâleti Şükrü Kaya imzasıyla Adliye ve Maarif Vekâletlerine gönderilen 25.2.1938 tarih ve 8778 sayılı yazı.

${ }^{22}$ EGMA. D.13217-146, K.26563; Erzurum Valisi Hilmi Balcı imzasıyla Dâhiliye Vekâletine gönderilen 2.3.1939 tarih ve Em.430/159 say1lı yazı.

${ }^{23}$ EGMA. D.13217-148, K.26602; Dâhiliye Vekâletinden 3üncü Umumi Müfettişliğine gönderilen 24.1.1939 tarih ve 6647 sayılı şifre.

${ }^{24}$ EGMA. D.13219-122, K.29448; Trabzon Valisi Osman Sabri Adal imzasıyla Dâhiliye Vekâletine gönderilen 21.2.1940 tarih ve 210/1337 say1lı yazı.

${ }^{25}$ EGMA. D.13219-107, K.27219; Urfa Valisi Kazım Demirer imzasıyla Dâhiliye Vekâletine gönderilen 5.2.1940 tarih ve Ş.1.3-151 sayılı yazı.

${ }^{26}$ EGMA. D.13219-103, K.26941; Giresun Valisi Muhtar Akman imzasiyla Dâhiliye Vekâletine 17.7.1940 tarih ve 379 sayılı yazı. 
imamı, ${ }^{27}$ Rize'de bir mahalle imamı ${ }^{28}$ adliyeye sevk edilerek muhtelif cezalara çarptırılmışlardır. Bu tür olayların artması üzerine Diyanet İşleri Reisi M. Şerafettin Yaltkaya 1942 yılında İstanbul Müftülüğü'ne bir yazı göndererek bu tür faaliyetlerin yasak olduğunu belirtmiştir: "Bazı Kur'an öğreticilerinin ilk tahsil çă̆ındaki çocukları kursa devam ettirdikleri istihbar edilmiştir. Bu gibi usulsüz hareketlere meydan verilmemesi lüzumu ehemmiyetle beyan olunur." 29

Bu dönemde yönetimin Kılık-Kıyafet Devrimi ile ilgili uyguladığı tedbirler, devrimlerin kökleşmesi ve halk tabanında tutunması için yürütülen çabaların çarpıcı bir örneğini oluşturmaktadır. Bu çerçevede güvenlik güçlerinin kılık-kıyafet konusunda çok duyarlı davranışlar sergilediği görülmektedir. "19.3.1940 tarihinde İçel'de kılık ve kıyafetinden şüphe edilen Kayserili Ahmet İbiş adındaki şahıs polis tarafından yakalanmıştır. Sorgusunda açıkça rejim, devrimler ve Atatürk aleyhinde sözler söyleyen şahıs hakkında zabıt tutulmuş, şahıs Nakşi ve Kadiri tarikatına mensup olduğunu itiraf etmiş, ancak yapılan doktor muayenesinde şuurunun bozuk olduğuna karar verilerek men-i muhakeme kararı verilmiştir., "30

Kılık-kıyafet konusunda polisin titizlikle takip ettiği bir diğer konu ise, kadınların peçe, çarşaf ve peştamal giymesinin yasaklanması olmuştur. 1935 yılında İçişleri Bakanlığınca yayınlanan bir tamimle bu giysilerin giyilmesinin yasaklandığı bildirilerek kolluk kuvvetlerinin gerekli tedbirleri alması istenmiştir. ${ }^{31} \mathrm{Bu}$ yasak Millî Şef döneminde de devam etmiş ve Emniyet Umum Müdürlüğ̈̈, 1940 yılında 'Medeni kıyafete aykırı kisve taşıyanlar hakkında' bir emir ${ }^{32}$ yayınlayarak, devrimlere aykırı ve belli bir maksada yönelik olarak kasketlerini ters giyen erkekler ile peştamal giyen, yüzünü örten, peçe takan kadınların takip edilip bunlara müsaade edilmemesini istemiştir. Bu yazıya cevaben Aydın Vilayeti Emniyet Müdürlüğü'nce gönderilen bir yazıda endişe edilecek bir durumun olmadığı belirtilmektedir. Yazıda "Vilayet dâhilinde erkek kıyafeti kasaba ve köylerde tamamen medeni şekildedir. Kasketlerini tersine giyen belki görülmüsstür. $\mathrm{Bu}$ gibiler ya seksenlik ihtiyarlardır ki evlerinden, köylerinden dışarı çıkmazlar

${ }^{27}$ EGMA. D.13217-102, K.22892; Konya Valisi Nizamettin Ataker imzasıyla Dâhiliye Vekâletine gönderilen 5.4.1940 tarih ve Ş.I.509 sayılı yazı.

${ }^{28}$ EGMA. D.13217-133, K.26572; Rize Valisi Hüsnü Uzgören imzasıyla Dâhiliye Vekâletine gönderilen 6.10.1941 tarih ve 2681 sayılı yazı.

${ }^{29}$ 19.8.1942 tarih ve 3254 sayılı yazı. Bkz.: Sadık Albayrak, Türkiye'de Din Kavgası, İstanbul, Şamil Yayınevi, 1984, s. 34.

${ }^{30}$ EGMA. D.13219-132, K.35124; İçel Valiliğinden Dâhiliye Vekâletine gönderilen 20.3.1940 tarih ve Em.431 sayılı yazı.

${ }_{31}$ İçişleri Bakanının imzası ile Umumi Müfettişliklere ve Valiliklere gönderilen 22.7.1935 tarih ve 6936 sayılı yazı, Belge No: 13216-7/1, bkz., 150likler, Kubilay Olayı, Çarşaf-Peçe-Peştemalla Örtünme Sorunlart: Polis Arşiv Belgeleriyle Gerçekler, Polis Dergisi, Yayın No: 129, EGM Yayınları, Ankara, 1998, s. 89-90.

${ }^{32}$ EGMA. Emniyet Genel Müdürlüğü tarafından illere gönderilen 20.4.1940 tarih ve EUM- Ş.I.C.18007 say1l genelge, D.13216-7. 
veyahut beş vakit namazına devam eden koyu sofuların abdest alırken, namaz kılarken kasketlerini tersine çevirenlerdir ki bunlar da ancak camilerde, abdest aldıkları çeşme başlarında görülebilir. Bunlar haricinde her hangi bir irticai fikir ve maksada kapılan ve şapkalarını tersine giyen kimse yoktur." denilmekte ve kadınların kasabalarda çok medeni tarzda giyindiği, köylerde hiçbir kadının peçe takmadığı, peştamal kullanımının gittikçe azaldığı vurgulanmaktadır. ${ }^{33}$

Aynı şekilde bu dönemde şapka kanununa muhalefet edenlerin takibi ve tahkikatları konusunda polis yoğun çaba göstermiştir. 19 Eylül 1939 günü Adapazarı'nın Akyazı Nahiyesi Uzunçınar köyünde 16 yaşındaki Kamil Karabaş, şapka kanununa aykırı başında takke ile yakalanıp hakkında işlem yapılmıştır. ${ }^{34}$ Şapka kanununa aykırı takke giydiğinden polis tarafından yakalanıp adliyeye teslim edilen İlyas Beğindik, Kayseri Sulh Ceza Mahkemesi tarafından (1) lira hafif para cezasına mahkûm edilmiştir. ${ }^{35}$ Emniyet Polis Müfettişi Ziya Oral tarafından Bingöl ilinin genel durumuna dair yapılan inceleme sonucunda yazılan bir raporda "geri fikirliliğin bir neticesi olarak bu havalide halen şapka giyilmeyip, yünden yapılmış bir nevi külah giyilmektedir. Şapkayı şehir ve kasabaya gelirken kullanılan bir meta haline sokmuş bulunan bu yobazlardan şapka tedarik edememiş olanlar kasaba içinde başı açık gezmektedir. Velhasıl kolluk gözünden uzak bulundukça şapka giyilmemektedir" ${ }^{36}$ denilmektedir.

Devrim kanunlarına aykırı faaliyetler konusunda polisin takip ettiği insanlar sadece Kılık-kıyafet Kanunu'na veya Şapka Kanunu'na muhalefet edenlerle sınırlı değildi. Yönetimi eleștiren, dini propaganda yapan, üfürükçülük yapan, devrimlere aykırı faaliyetlerde bulunanlar ${ }^{37}$ da polis tarafından sıkı bir şekilde takip edilerek, haklarında yasal işlem yapılmıştır. Örneğin, Dersiam-vaiz Şevket Sezen Kocaeli’de, Ramazan ayında yaptı̆̆ 1 vaazda, Cumhuriyetin 16. yıl dönümü münasebetiyle vilayet tarafından verilen Cumhuriyet balosunu eleştirerek 'balo Ramazandan sonra yapılmış olsaydı, Müslümanların hissiyatına hürmet edilmiş olurdu' şeklinde sözler sarf ettiğinden, vaaz vermekten men edilmiştir. Ancak mahkemede 163.

${ }^{33}$ 150likler, Kubilay Olayı, Çarşaf-Peçe-Peştemalla Örtünme Sorunları, 25.04.1940 tarih ve 13216-7/2 sayıll belge, s. 95 .

${ }^{34}$ EGMA. D.13219-140, K.38097; Kocaeli Valisi Ziya Tekeli imzasıyla Dâhiliye Vekâletine gönderilen 27.9.1939 tarih ve 1729 sayılı yazı.

${ }^{35}$ EGMA. D.13219-141, K.38430; Kayseri Valisi Şefik Refik Soyer imzasıyla Dâhiliye Vekâletine gönderilen 9.4.1940 tarih ve 4969 sayılı yazı.

${ }^{36}$ EGMA. D.11215-1, K.56857; Emniyet Polis Müfettişi Ziya Oral tarafından Dâhiliye Vekâletine gönderilen 8.5.1945 tarih ve 231 sayılı yazı.

$37 \mathrm{Bu}$ çerçevede, Diyanet İşleri Reisi M. Şerafettin Yaltkaya imzasıyla Mut Müftülüğü'ne gönderilen bir yazıda, 5290 sayılı kanunla kaldırılan Ağa, Hacı, Hafız, Hoca, Molla Efendi, Bey, Beyefendi, Paşa, Hanım, Hanımefendi ve Hazretleri gibi lakap ve ünvanların resmi yazışmalarda kullanılmaması istenilmiştir. Bkz.: Başbakanlık Cumhuriyet Arşivleri, [BCA]. Belge Tarih ve Sayısı: 24.7.1942 - 1067, Dosya: 86-395, Yer No: 4.36..15. 
maddeden takibata gerek olmadığına karar verilmiştir. Haymana kazasında, Bayram namazından önce hutbede (Namaz kılıp oruç tutmayanlar yahut oruç tutup da kllmayanlar ala domuz, bunların hiçbirini yapmayanlar kara canavar, kinci olanlar ise deve suretindedirler) şeklinde vaaz veren Mehmet Hoca adliyeye sevk edilmiş, ancak savcılık takibata mahal olmadığına karar vermiştir. ${ }^{38}$ Dersiamlardan Ohrili Hüsrev (Aydınlar) hoca Fatih Camii'nde verdiği vaazda 'Biz atimizi küfür ve delalette bırakıyoruz, inşallah başımıza kudretli birisi gelir de bizi kurtarır' şeklinde sözler sarfetmesi üzerine adliyeye sevk edilmiştir. ${ }^{39}$ Ancak Fatih Asliye Mahkemesinde 18 Haziran 1940 tarihinde beraat kararı etmiştir. ${ }^{40} 12$ Aralık 1939 günü Bitlis'te katırcı Sıddık Okumuş adlı bir vatandaş, Şeyh Karip zaviyesine mum yakarken suçüstü yakalanarak adliyeye sevk edilmiştir. ${ }^{41}$

Suudi Krallığı vatandaşı İbrahim Selman (Samman) adlı birisinin çeşitli illerde dolaşmaya başladığı, 16 Aralık 1939 tarihinde Balıkesir'de kendisini Mekke baş imamı süsü vererek halkı hacca gitmeye teşvik ettiği ihbar edilmiştir. Ancak İzmir, Denizli, Isparta, Aydın, Konya, Seyhan ve Muğla Valiliklerinden gelen yazılarda adı geçen şahsın zararlı bir faaliyeti görülmediği bildirildiğinden 7 Ocak 1940'ta hakkındaki takibat durdurulmuştur. ${ }^{42} 1940$ yılında İzmir'de 10 kişi Bektaşi tarikatına mensup oldukları için tutuklanmıştır. ${ }^{43}$ Aynı yıl Adliye Vekâleti, Cumhuriyet Savcılığına bir tamim yayınlayarak 677 sayılı yasaya aykırı hareket ederek şeyhlik ve dervişlik yapanları izleme talimatı vermiştir. ${ }^{44}$

Evinde üfürükçülük ve muskacılığa yarar kitaplar bulundurduğundan, aynı zamanda Nakşibendî tarikatına mensup olduğundan polis tarafından sürekli takip edilen Şeyh Salih adlı bir vatandaş artık şüpheli hareketlerde bulunmadığı, çok ihtiyar ve aciz ve dilenerek geçinmekte olduğu anlaşıldığından polis tarafından takip edilmesinden vazgeçilmiştir. ${ }^{45}$ Benzer şekilde "Nakşibendî tarikatına mensup olup kadın ve erkekler üzerinde nüfuzu olması ve irticai hareketinden ötürü Menemen Divan-1 Harbince bir sene üç ay hapis ve 50 lira para cezasına mahkûm Halil Temizkan'ın biraz

${ }^{38}$ EGMA. D.13219-145, K.39028; Ankara Valisi Nevzat Tandoğan imzasıyla Dâhiliye Vekâletine gönderilen 22.11.1939 tarih ve 14119/26247 say1lı yazı.

${ }^{39}$ EGMA. D.13219-143, K.38875; İstanbul Valisi Y. Hüdai Karataban imzasiyla Dâhiliye Vekâletine gönderilen 11.12.1939 tarih ve 24195/25574 sayılı yazı.

${ }^{40}$ EGMA. Dosya No: 13219-143, Arsiv K.38875; İstanbul Valisi Y. Hüdai Karataban imzasıyla Dâhiliye Vekâletine gönderilen 5.7.1940 tarih ve 14975/15914 sayılı yazı.

${ }_{11}$ EGMA. D.13219-144, K.390;. Bitlis Valisi Rifat Şahinbaş imzasıyla Dâhiliye Vekâletine gönderilen 16.12.1939 tarih ve 2577/11492 sayılı yazı.

${ }^{42}$ EGMA. D.13219-150, K.39880; Balıkesir Vali Y. Abdülkadir Keskin imzasıyla Dâhiliye Vekâletine gönderilen 21.12.1939 tarih ve 2391 sayılı yazı.

${ }^{43}$ Tasviri Efkâr (14 Haziran1941); Gotthard Jaeschke, Türkiye Kronolojisi (1938-1945),

(Çev. Gülayş̧e Koçak), Türk Tarih Kurumu Basımevi, Ankara, 1990, s. 51.

${ }^{44}$ Tan (2 Temmuz 1940)

${ }^{45}$ EGMA. D.13217-13, K.3109; Zonguldak Valiliğinden Dâhiliye Vekâletine gönderilen 14.7.1941 tarih ve K.I. sayıl1 yazı. 
daha takip altında tutulmasına karar verilmiştir. ${ }^{46}$ Geçmiş dönemde takip edilen şahıslardan olan ve eski Galatasaray muallimlerinden Zeynelabidin (Gülcü)'ye, 1940 yılında iyi halinden dolayı vaizlik yapması için izin verilmiştir. Ancak sonraki yıllarda "menfi ruhlu, hükümet ve rejim aleyhtarı" olmaktan, rejim ve inkılâplar aleyhine söz söylemekten, Arapça yazılı kitaplar bulundurmaktan dolayı vaizliğine tekrar son verilmiştir. ${ }^{47}$

Kocaeli Akça Camiinde 1 Ekim 1943 tarihinde kılınan Bayram namazından sonra vaaz veren Şevket Sezen "Muhitimiz layiktir, fakat din yoktur, mekteplerde ise din olmadi $\breve{g}$ gibi dine de alaka yoktur. Siz babalar evlatlarınızı evlerinizde din dersi ögretiniz, namaza ve camilere alıştırınız, bu babdaki mesuliyet-i maneviye velilere aittir, sonunda siz mes'ul olursunuz" şeklinde sözler sarfetmesi üzerine adliyeye sevkedilmiştir. Cumhuriyet Müdde-i Umumiyesinin 21.12.1943 tarih ve 390 sayılı kararı ile bu sözler, mahiyet itibari ile dini hissiyatı tahrik gibi müstelzim-i ceza bir suç mahiyetinde görülmemiş, takibata mahal yok kararı verilmiştir. ${ }^{48}$

Başta Arap harfleri ile eğitim verilmesi konusu olmak üzere güvenlik güçlerini uğraştıran bu tür olayların yanı sıra, yine güvenlik güçlerinin yoğun mesai harcadığı bir diğer konu Ezan'ın Türkçe okunması zorunluluğuna karşı gösterilen tepkiler olmuştur.

\section{Türkçe Ezan Uygulamasında Karşılaşılan Sorunlar}

Yakın tarihimizde uzun süre tartışmalara neden olmuş, günümüzde bile siyasi tartışmalara kaynaklık eden ve Millî Şef döneminde, halkın güvenlik güçleriyle sıkça karşı karşıya geldiği konuların bir diğeri de Ezanın ve Kur'an'ın Türkçe okunması ${ }^{49}$ uygulaması olmuştur.

Türkçe ezan-kamet uygulaması daha ilk günlerden itibaren çeşitli direnmelerle karşılaşmıştır. Bu uygulamaya ilk kitlesel tepki 1 Şubat 1933'te

${ }^{46}$ EGMA. Dosya No: 13219-138, K.37004; 14 Mayıs 1943 tarihinde Balıkesir Valisi Faik Türel, Vilayet Jandarma Komutanı Salih Özcoşkum, Emniyet Müdürü Tacettin Ortaç imzasıyla alınan karar örneği.

${ }^{47}$ EGMA. D.13219-24, K.896; Kocaeli Valiliğinden Dâhiliye Vekâletine gönderilen 21.10.1941 tarih ve 2951 sayıli yazı.

${ }_{48}$ EGMA. D.13219-149, K.39409; Kocaeli Valisi Agah Alp imzasıyla Dâhiliye Vekâletine gönderilen 6/1. Teşrin 1943 tarih ve 3052 sayılı yazı.

${ }^{49}$ Cumhuriyet'in ilk yıllarında din ve devlet işlerinin birbirinden ayrılması yolundaki önemli adımlardan birisi "Íbadetin Türkçeleştirilmesi" idi. Bu amaçla 1928 yılında M. Fuat Köprülü başkanlığında oluşturulan komisyonun hazırladığı raporda "İbadet lisanı Türkçe olmalıdır. Ayinlerin, duaların, hutbelerin Türkçe şekilleri kabul ve istimal edilmelidir" önerisi getirildi. Bkz.: Gotthard Jaeschke, Yeni Türkiye'de İslamcıllk, (çev. Hayrullah Örs), Bilgi Yayınevi, Ankara, 1972, s. 44-45. Bu teklif uygulamaya geçirilemedi. Ancak bu konuda ilk somut adım olan Türkçe ezan ilk olarak 29 Ocak 1932 tarihinde İstanbul Fatih Camiinde okundu. Bkz. Cumhuriyet (31.02.1932). Diyanet İşleri Başkanlığı 1932 yılında müftülüklere bir tamim göndererek Türkçe Ezan ve Kametin zorunlu olduğunu, buna riayet etmeyenlerin şiddetle cezalandırılacağını belirtti. 
Bursa'da görüldü. ${ }^{50}$ Bundan sonraki süreçte ezanın Türkçe okunması için çok sıkı tedbirler alınmasına rağmen ülkenin bazı yerlerinde ezan yine Arapça okunmaya devam etti. ${ }^{51}$ Bu yeni uygulamanın tüm Türkiye'de tatbiki hayli zaman aldı. Daha doğrusu bunda tam bir başarı sağlanamadı. Ancak Türkçe ezan uygulamasına gösterilen tepkiler incelendiğinde, Bursa olayı dışında dikkate değer bir kitle gösterisi ve toplumsal olay yaşanmadığ 1 ve yasağ 1 çiğneyenlerin bu tepkilerini kişisel eylemlerle gösterdikleri görülmektedir. Emniyet Genel Müdürlüğü arşiv kayıtlarında ve basın organlarında yasağı çiğneyenler hakkında yapılan işlemlerle ilgili birçok olaya rastlamak mümkündür.

İlk uygulamaya geçildiği tarihten itibaren başlayan yasak karşıtı eylemlerin, Atatürk'ün vefatından kısa bir süre önce de devam ettiği ve birçok insan hakkında işlem yapıldığı görülmektedir. Bu konuda emniyet arşivlerinde yer alan olaylardan bir kaçı şöyledir: Isparta'da Uzun oğlu Ahmet Usta'nın evinde okutulan bir mevlit esnasında Arapça tekbir alan Hilmi Alâeddin isimli şahıs adliyeye sevk edilmiştir. ${ }^{52}$ Bayburt ilçesi Ulucami müezzini hasta olması dolayısıyla 15 Şubat 1938 günü sabah namazına gelen cemaatten mezkûr ilçeden Şükrü Yıldız, Arapça ve Türkçe karışık olarak kamet getirdiğinden dolayı savcılığa şikâyet edilmiştir. ${ }^{53}$ Konya'da Kurban Bayramı namazında iki kişi duadan sonra Arapça tekbir aldıkları tespit edilip adliyeye sevk edilmiş, ancak herhangi bir cezaya çarptırılmamıştır. ${ }^{54}$ Erzurum Vilayeti Hınıs kazasında Ramazanda imamlık yapmış olan Molla Ahmed Arapça sela verdikten sonra kaçmış ve

${ }^{50}$ Ulu Cami'deki vaizin tahrikleri ile uygulamayı bahane eden bir grup halk sokağa dökülerek valilik önünde gösteri yaptı. Ancak olaylar çok fazla genişlemeden bastırıldı. Olaya çok sert tepki gösteren Atatürk bizzat Bursa'ya gitti. Olayın Elebaşılarından olan Nakşibendî şeyhi Kozanlı İbrahim yakalanarak ağır bir cezaya çarptırıldı. Güvenlik kuvvetleri, olaya ön ayak olanları tutukladı, ihmali görülen memurlara işten el çektirildi. Bkz.: İlhami Soysal, "Mezhepler Tarikatlar", Cumhuriyet Dönemi Türkiye Ansiklopedisi, Cilt: V, İletişim Yayınları, İstanbul, 1983, s. 1366.

${ }^{51}$ Bu konuda polis arşivlerinde ve basında yer alan bazı olaylar şöyledir: "Arapça ezan okumak meselesinden dolayı mevkuf bulunan Çarş1 Meydanı ve Ortahisar camileri müezzinleri Hamdi, Musa, Halil Efendilerin evrakları ile birlikte Çorum'a gönderilmiştir." Bkz.: Aksam (1.3.1933). Urfa'da vazifesi olmadığ 1 halde Arapça kamet eden cemaatten bir şahıs, Cami Müezzininin ihbar etmesi üzerine yakalanıp Adliye'ye sevk edilmiştir. Bkz.: EGMA. D.13217-9, K.1999; Urfa Valiliğinden Dâhiliye Vekâletine gönderilen 27.2.1933 tarih ve 802/72/18/187 sayılı yazı. Benzer sekilde Corum'da Bayram namazından sonra Arapça ezan okuyan bir vatandaş ağır cezada yargılanmıştır. Bkz.: EGMA. D.13219-133, K.36252; Çorum Valiliğinden Dâhiliye Vekâletine gönderilen 10.5.1933 tarih ve 180 sayılı yazı. Sonraki yıllarda muhtelif illerde Türkçe ezan uygulaması ufak çaplı yürüyüşlerle protesto edilmiştir.

52 EGMA. D.13217-13, K.3109; Isparta Valiliğinden Dâhiliye Vekâletine gönderilen 6.1.1938 tarih ve 26426/12 sayılı yazı.

${ }^{53}$ EGMA. D.13217-17, K.3111; Gümüşhane Valisi N. M. Tosun imzasıyla Dâhiliye Vekâletine gönderilen 18.2.1938 tarih ve Em.I-47 sayılı yazı.

${ }^{54}$ EGMA. D.13217-22, K.3394; Konya Valiliğinden Dâhiliye Vekâletine gönderilen 15.2.1938 tarih ve 216 sayılı yazı. 
aranmasına başlanmıştır. ${ }^{55}$ Arapça tekbir almaktan suçlu Şarkîkaraağaç ilçesi inhisarlar takip memuru Hilmi Aydın 3 lira hafif para cezasına çarptırılmıştır. ${ }^{56}$

Millî Şef döneminde de yasağa rağmen ezanı Arapça okumakta 1srar edenler olduğu görülmektedir. Ancak bu konuda tavizsiz bir politika güdülmüs ve yasak katı bir şekilde uygulanmıştır. Bu çerçevede Arapça ezan yasağına karşı gelen birçok insan tutuklanarak muhtelif cezalara çarptırılmıştır. Örneğin, Silivri kazasının Seymen köyünde ziraat memuru Behçet, Arapça kamet getirmekten 1 gün hapis cezasına çarptırılmıştır. ${ }^{57}$ Yozgat'ın Boğazlıyan kazasında Büyük Camii'nde Bayram namazında Arapça tekbir getiren Ali Gence'nin kastı olmayıp yanlışlık neticesi okuduğuna kanaat getirilerek takibat icrasına mahal olmadığına karar verilmiştir. ${ }^{58}$

Arapça ezan okuma yasağının taraflar arasında bir suçlama malzemesi olarak kullanıldığ anlaşılmaktadır. 1941 yılında Arapça ezan okuyanlara getirilecek cezaları düzenleyen yasanın görüşülmesi esnasında söz alan, Rasih Kaplan'ın anlattı̆̆ 1 bir olay bu iddiaya bir örnek teşkil ediyor: "Antalya'dayım. Savcının yanında müftüyü gördüm. Hayret ettim. Çünkü Millî mücadelede çok çalışmış, karakterli bir arkadaşımızdır. Gittikten sonra hayretle sordum. Savcı dedi ki, birisi imam olmak istemiş, polis kaydında, uyuşturucu madde kullandığ 1 görülmüss. Müftü, (Sen imam olamazsın) demiş. İşte bu adam savcıya bir ihbarname veriyor; 'Dün öğle namazında camiye gittim, müftü camide idi, müezzin Türkçe kameti getirdikten sonra müftü namaza başlamadı, dikkat ettim dudakları kıpırdıyor, Arapça kamet getiriyordu.' Savc1, bunun üzerine takibata başlamış." ${ }^{99}$

1941 yılına kadar Arapça ezan okuyanlara verilecek cezalar konusunda yasal boşluktan dolayı bir belirsizlik yaşanmıştır. Bu konuda Emniyet Genel Müdürlüğü arşivlerinde Arapça ezan-kamet okuma iddiasıyla savcıllı̆̆a sevk edilen birçok insanın, farklı farklı cezalara çarptırıldıkları veya hiç ceza almadan beraat ettikleri görülmektedir. Diyanet İşleri Başkanlığı'nın genelgesine rağmen Arapça ezan okumakta 1srar edenlere; biraz hukuk zorlanarak ${ }^{60}$ çeşitli cezalar verildi. Buna karşın, örneğin, Gümüşhane

55 EGMA. D.13217-21, K.3395; Dâhiliye Vekâleti Şükrü Kaya imzasıyla Maarif Vekâletine gönderilen 24.2.1938 tarih ve 8510 sayılı yazı.

${ }^{56} E G M A$. D.13217-7, K.593; İsparta Valiliğinden Dâhiliye Vekâletine gönderilen 18.4.1938 tarih ve 28791/630 say1l yaz1.

${ }^{57}$ EGMA. D.13217-111, K.23756; İstanbul Valiliğinden Dâhiliye Vekâletine gönderilen 14.2.1939 tarih ve 2431/2664 say1l yazi.

${ }^{58}$ EGMA. D.13217-118, K.24949; Yozgat Valisi Fevzi Gürelden imzasıyla Dâhiliye Vekâletine gönderilen 26.3.1940 tarih ve 523 sayılı yazı.

59 "Ezan 18 yıl Türkçe okundu", Hürriyet (16.6.2000).

${ }^{60}$ Hasan Pulur, “Arapça ezan Türkçe ezan...”, Milliyet (2.12.2004) 
Cumhuriyet Müddeiumumîsi 1938 yılında "Arapça ezan okuma fiiline kanunen bir ceza tayin edilmemiş olup, Türk ceza kanununun birinci maddesi mucibince kanunun sarih olarak suç saymadığı bir fiil cezalandırılamayacağından bahisle takibata mahal olmadı ̆̆ına"61 karar vermiştir. Ayrıca Arapça ezan okumaktan dolayı ceza alanlarla ilgili kararlar Yargitay tarafından da birkaç defa bozulmuştur. ${ }^{62}$

Arapça ezan yasağına uymayanlara verilecek cezalar konusundaki yasal boşluktan doğan sorunlar giderek artınca Arapça ezan okuyanların cezalandırılması için bir yasa çıkarılması gündeme geldi. Refik Saydam hükümetinin TBMM'ye sevk ettiği Türk Ceza Kanunu değişikliği, Arapça ezan okuyanlara üç aya kadar hafif hapis, on liradan iki yüz liraya kadar hafif para cezası öngörüyordu. Kanun değişikliği, 23 Mayıs 1941 günü Meclis'te görüşülmeye başlandı. Görüşmeler esnasında Laiklik ve millîyetçilik üzerinde yoğunlaşan tartışmalarda "Arapça ezan okuyanların" değil, "Türkçe ezan okumayanların" cezalandırılması istendi. Ancak bu görüşmelerden sonra yasa hükümetin istediği şekilde çıktı. Böylece Arapça ezan ve kamet okumaya devam edenler 1941 yılına kadar "kamu düzenini sağlamaya yönelik emirlere aykırılık" suçundan cezalandırılırlarken, 2 Haziran 1941 tarihinde 4055 sayılı Türk Ceza Kanununun Bazı Maddelerini Değiştiren Kanunla Türk Ceza Kanunu'nun 526'ıncı maddesinin ikinci fıkrasına eklenen "Arapça ezan ve kamet okuyanlar üç aya kadar hafif hapis, on liradan 200 liraya kadar hafif para cezasıyla cezalandırılırlar" ${ }^{163}$ hükmünde cezai bir yaptırım getirilerek, yasal bir düzenlemeye gidilmiştir. Buna göre görev diş1 dâhil herhangi bir yerde, Arapça ezan okuyanlar da cezalandırılacaktı.

Ancak tüm yaptırımlara karşın, yasă̆ın çiğnenmesi devam etmiş, özellikle güvenlik güçlerinin ulaşmakta zorluk çektiği yerlerde Arapça ezan okunmaya devam etmiştir. Örneğin 1945 yılında doğu illerinde teftiş yapan bir polis müfettişi, Bingöl'de köylerde hâlâ Arapça ezan okunmaya devam edildiğini söylemektedir. ${ }^{64}$ Benzer bir durum, dönemin bir tanığ 1 tarafından "Köyde eski Türkçe [Arapça] ezan okurlardı. Böyle Allahüekber, Allahüekber... Eski Türkçe ezan okumak yasaktı o zamanlar. Ezan zamanı, candarmalar gelirdi, ki bakalım bunlar nasıl okuyorlar ezanı diye.

${ }^{61}$ EGMA. D.13217-17, K.3111; Gümüşhane Cumhuriyet Müddeiumumîsi Hayri Ertürk (5986)'nın Emniyet Komiserliğine gönderdiği bilatarih ve 1103 sayılı cevabi yazı.

${ }_{62}$ İsmet Bozdağ, Zaferlerle ve Şereflerle Dolu Bir Hayat: Celal Bayar, Tercüman Yayınları, İstanbul, 1986, s. 108

${ }^{63}$ TBMM Kavanin Mecmuası, Devre VI, İçtima: 2, 1 Teşrinisani 1941, Cilt: 22, s. 721; Jaeschke, Yeni Türkiye'de İslamcılık, s. 110.

${ }^{64}$ EGMA. D.11215-1, K.56857; Emniyet Polis Müfettişi Ziya Oral tarafından Dâhiliye Vekâletine gönderilen 8.5.1945 tarih ve 231 sayılı yazı. 
Candarmaları gördükleri zaman bizimkiler yeni ezanları okurlardı, 'Tanrı uludur, Tanrı uludur' diye" 65 şeklinde dile getirilmektedir.

Cemaat ve cami görevlilerinin Türkçe ezan okuma hususunda, ilginç kaçamak yollara başvurdukları görülmektedir. Ezanın çocuklara ve akıl hastalarına okutturulması, ezanın Türkçe olarak yüksek sesle okutulmasından sonra Arapça'sının hafif bir sesle okutulması veya görevli olmayan kişilere Arapça'sının okutulması başvurulan bu yollar arasındaydı. Polis kayıtlarında Arapça ezan yasağını çiğnemekten dolayı yakalananlar arasında çok sayıda akli dengesi bozuk vatandaşın bulunması bu kaçamak yolların sıklıkla uygulandığını göstermektedir. Örneğin Karamürsel'in Ayazma köyünden Boşnak asıllı Bekir (Duran) Çarşı camiinde Arapça ezan okumaktan dolayı adliyeye sevk edilmiş, ancak cezai ehliyeti olmadığından serbest bırakılmış, adı geçen şahsın yine Arapça Ezan okumaya devam etmesi üzerine 9.1.1939'da Bakırköy Hastanesine sevk edilmiştir. Arapça ezan okumaktan dolayı adliyeye sevk edilen Yusufeli kazasından soyadı olmayan Hüseyin, 'şuur bulanıklığı' olduğu doktor raporuyla tespit edilerek serbest bırakılmıştır. ${ }^{66}$ Benzer şekilde, 27.2.1939 tarihinde Yeni Foça kazasında camide kimsenin olmadığı sırada, Kâzım adında bir şahıs Arapça ezan okurken yakalanmış, ancak sanığın Bahriye yüzbaşısı iken akıl hastalığından emekliye ayrılmış bir deli olduğu anlaşıldığından serbest bırakılmıştır. ${ }^{67}$ Arapça ezan okuyan çocuklar ve akı1 hastaları cezai ehliyetleri olmadığından yakalandıklarında bir işlem yapılamıyor, böylece yasak delinmiş oluyordu. 18 Temmuz 1945 tarihinde Millî Kalkınma Partisi'nin kuruluşuyla başlayan çok partili hayatla birlikte Türkçe ezan ve diğer uygulamalara karşı girişilen hareketler hemen bütün toplum katmanlarına yayılmaya başladı. ${ }^{68} 1946$ yılında ezanın Türkçe okunması açıktan eleştirilmeye başlandı ve yasağa karşı gelmeler devam etti. Adalet Bakanı Fuat Sirmen'in bir bildirisine göre 1947 yılında Arapça ezan okumak suçundan 29 kişi tutukland ${ }^{69}$ Özellikle M. Kemal Pilavoğlu şeyhliğindeki Ticaniler bu işin öncülüğünü yapıyordu. Tarikat mensupları, resmi zevatın bulunduğu ortamlarda ezanı Arapça olarak okuyor ve bu yasağa kendilerince direniyorlardı. Arapça ezan eylemcisi Ticaniler değişik ortamlarda da, örneğin bir millî maçta Dolmabahçe Stadı'nda, Ankara valisinin huzurunda ve ülkenin değişik şehirlerinde, Arapça ezan okuma eylemi yapıyorlardı. Bu grup üyeleri en çarpıcı eylemlerini, 4 Şubat 1949 tarihinde Türkiye Büyük Millet Meclis'inde gerçekleştirdiler. Meclis müzakerelerinin devam ettiği

${ }^{65}$ Tarihe Bin Canlı Tanık, "Taş taşa değmeyince duvar olmaz", İçimizden Biri Ahmet Kaya, Milliyet-Pazar (10.8.2004).

${ }^{66}$ EGMA. D.13217-50, K.26884; Çoruh Valiliğinden Dâhiliye Vekâletine gönderilen 29.8.1938 tarih ve $1495 / 1598$ sayılı yazı.

${ }^{67}$ EGMA. D.13217-147, K.26562; İzmir Valiliğinden Dâhiliye Vekâletine gönderilen 28.2.1938 tarih ve 286/2 sayılı yazı.

${ }^{68}$ Tarık Zafer Tunaya, İslamcılık Cereyanı, Baha Matbaası, İstanbul, 1962, s. 191.

${ }^{69}$ Jaeschke, Yeni Türkiye'de İslamcılık, s. 110. 
sırada dinleyici locasında bulunan tarikat mensubu iki kişi ayağa kalkıp yüksek sesle Arapça ezan okuyarak yasağ $\breve{1}_{\text {protesto etti. }}^{70^{3}}$ Dış basına da yansıyan bu olayı, gazeteler "görülmemiş hadise"171 olarak yorumladılar. 18 yıl aralıksız süren ${ }^{72}$ Arapça Ezan ve kamet yasağı, 1950 yılında Adnan Menderes Hükümeti tarafından çıkarılan 5665 sayılı yasayla kaldırıldı.

$\mathrm{Bu}$ yasağın uygulanması ve ihlal edenlerin yakalanmasında güvenlik kuvvetlerine özellikle de jandarmaya çok iş düşmüştür. Emniyet arşivlerinde mevcut belgelerde, bu yasağın uygulanması konusunda birçok vatandaşın büyük bir duyarlılıkla derhal güvenlik kuvvetlerine haber verdikleri ve güvenlik kuvvetlerinin de bu tür ihbarları derhal değerlendirerek, yasağı çiğneyen şahıslar hakkında gerekli yasal işlemleri başlattıkları anlaşılmaktadır.

Ezanın Türkçeleştirilmesi çalışmaları ile birlikte yine Atatürk tarafından başlatılan Kur'an'ın Türkçe okunması yönündeki çalışmalar, Millî Şef döneminde tekrar gündeme gelmiştir. 9 Ocak 1942 tarihinde Türk Dil Kurumu yeni bir Kur'an çevirisine karar vermiştir. ${ }^{73}$ Gürtaş'a göre İnönü'nün, Türkçe Kur'an ile namaz kılınması yönünde teşebbüsleri olmuş, ancak siyasi atmosfer bu amacın gerçekleştirilmesine engel olmuştur. ${ }^{74}$

\section{İslamcı Akımlar ve Tarikatlar}

Millı̂ Şef dönemi, diğer siyasi akımlarda ${ }^{75}$ olduğu gibi İslamcı akımlar üzerinde de sıkı bir takibin yaşandığı, örgütlenme yollarının kapatıldığı ve yasaların tavizsiz şekilde uygulandığı bir dönemdir. Polisler arasında her ne kadar "Türkiye' de yaşayan on sekiz milyon halk içinde muzur cereyanlar peşinde koşanlar ve bu cereyanlara tabi olanlar yoktur, denebilir (...) Zaman zaman halkın dini hislerinden istifadeye kalkan şahıslara şurada burada tesadüf edilse de, bu nevi şahıslar eski yani ihtiyar nesil arasında olduğundan

70 "Meclis’te garip bir vaka. İki adam bağıra bağıra Arapça ezan okumaya başladılar." Hürriyet (05.02.1949)

${ }_{71} 5$ Şubat 1949 tarihli Cumhuriyet, Milliyet, Kader gibi gazeteler olayı manşetten verdiler. Eylemi gerçekleştiren Muhittin Ertuğrul ve Osman Yasin adlı şahısların daha önceleri çeşitli kereler Arapça ezan okumak suçundan mahkum oldukları anlaşıldı. Her iki şahıs hakkında da soruşturma açıldı. T.B.M.M. Tutanak Dergisi, C. XVI, Dönem: 8, 1949, s. 37.

${ }^{72}$ Altan Öymen anılarında, Türkçe ezan deneyimin öyküsünü ayrıntılı olarak anlatmaktadır. Bkz. Altan Öymen, Değişim Yılları, Doğan Kitapçılık, İstanbul, 2004, s. 483-496.

${ }^{73}$ Jaeschke, Türkiye Kronolojisi (1938-1945), s. 69.

${ }^{74}$ Ahmet Gürtaş, Atatürk ve Din Eğitimi, DİB Yayınları, Ankara, 1982, s. 39-41.

${ }^{75} \mathrm{Bu}$ dönemde polis tarafından komünizm "en mühim ve en korkunç muzur cereyan" olarak görülmektedir. Bkz. Hüseyin Namık Orkun, "Nazmi Serim, İstihbarat-II: İç İstihbarat", Kitap incelemesi, Polis Dergisi, Yıl: 27, Sayı: 14-325 (1 Mayıs 1941), s. 158. Bunun yanı sıra İslamcılık ve Irkçılık istemeyen siyasi hareketlerdi. Necmettin Sadak, 17 Mayıs 1944 tarihli Akșam Gazetesindeki yazısında bu akımlarla ilgili "Gençliği tarih, coğrafya ve siyasete ters diussen İslamcılık, Turancılık ve Irkçılığa karşı koruyalım.!" uyarısını yapmaktadır. Bkz. Gotthard Jaeschke, Türkiye Kronolojisi (1938-1945), s. 99. 
bunları zaman kendiliğinden silip süpürecektir"”76 diye düşünenler varsa da, devrim kanunlarına ve laiklik uygulamalarına aykırı faaliyetler güvenlik kuvvetlerince çok sıkı bir şekilde takip edilmiştir. ${ }^{77}$ Gerek Cumhuriyetin ilanından itibaren gerekse Millî Şef döneminde sıkı bir şekilde takip edilen bu uygulama ve çağdaşlaşma programı, "toplumun gelenekçi kesimlerini oldukça tedirgin etmiştir." ${ }^{78} \mathrm{Bu}$ nedenle devrim kanunları ve çağdaşlaşma yolunda atılan adımları korumak amacıyla Millı̂ Şef döneminde yapılan uygulamalar, İslâmcı kesim tarafından bir "zulüm ve yıkılış" hareketi ve bu dönem "mukaddeslerin can çekiştiği" " bir devir olarak algılanmıştır.

1926 yılında çıkarılan Türk Ceza Kanunun (T.C.K.) 163. maddesi dini siyaset aracı olarak kullanma eyleminin yanı sıra devlet düzenini değiştirmek için dini cemiyet kurmayı da yasaklıyordu. Atatürk'ün ölümünden sonra bu madde tavizsiz bir şekilde uygulanmış ve laiklik karşıtı olarak görülen hareketleri cezalandırmak için en çok işletilen madde olmuştur. Bunun yanı sıra T.C.K.'nın 241, 242 ve 313. maddeleri siyasi alandaki bazı dini faaliyetlere getirilen yasakları ve uygulanacak cezaları düzenleyen diğer maddelerdi.

Ancak Millî Şef dönemindeki bütün sıkı ve tavizsiz uygulamalara rağmen, devrim kanunlarına ve laiklik uygulamalarına karşı çıkan kesim, faaliyetlerini bu dönemde alttan alta, gizlice devam ettirmiş ve özelikle kırsal kesimde yürütülen faaliyetlerle geniş bir taraftar kitlesi toplamışlardır. Etkileri günümüze kadar devam edecek olan bazı İslami oluşumlar ve tarikatlar bu dönemde, kendilerini tanımlama, tekrar kamusal alana çıkma ve sonraki yıllarda ortaya çıkacak muhalefet hareketlerinin tabanını oluşturma çabalarına girişmişlerdir. Alınan tedbirler sonucu devlet kademelerinde yer bulamayan bu kesim, gerçekleştirilen devrimlere karşı olan tepkilerini kendilerini fazla açığa çıkarmadan tarikatlar ve çeşitli gruplar vasıtasıyla yürütmüşlerdir.

Bu dönemde her ikisi de Nakşibendilikten gelen, Said-i Nursi'nin önderliğini yaptığı Nurculuk ile Süleyman Hilmi Tunahan'ın önderliğini yaptığı Süleymancılık tarikatları ile Kemal Pilavoğlu'nun başını çektiği Ticanilik hareketi, en çok adından söz ettiren akımlardı. Millî Şef yönetiminin izlediği ve gözetim altında tuttuğu bu tarikatlara karşı çeşitli tarihlerde müdahaleleri oldu. Ancak 1943 yılı, adı geçen bu tarikatlara ve

76 Hüseyin Namık Orkun, "Nazmi Serim, İstihbarat-II: İç İstihbarat", s. 156-157. Kitabın yazarı Nazmi Serim bu dönemde Ankara Polis Enstitüsü’nde Haberalma ve Detektiflik öğretmenliği yapmaktadır.

${ }^{77}$ Tunçay, "Türkiye Cumhuriyeti'nde Siyasal Düşünce Akımları", s. 1926.

${ }^{78}$ Cem Eroğul, "Çok Partili Düzenin Kuruluşu: 1945-71", içinde Geçiş Sürecinde Türkiye, (Der. İrvin Cemil Schick ve E. Ahmet Tonak), Belge Yayınları, İstanbul, 1992, s. 114.

${ }^{79}$ Hakikat Dergisi, Başyazı, Sayı: 109 (Ekim 2002), (Çevrimiçi), http://www.hakikat.com/dergi/109/bsyz10902.html, 11.04.2004.

${ }^{80}$ Cemil Meriç, Bu UUlke, İletişim Yayınları, İstanbul, 1994, s. 101. 
İslamcı akımlara karşı yönetimin somut bir mücadele başlattığı ve tutuklamaların başladığı bir yıl oldu.

Tek Parti yönetimini en çok uğraştıran bu hareketlerden en önemlisi Nurculuk akımı idi. Bu akımın kurucusu ve 'üstadı' Said-i Nursi ya da Bediüzzaman diye anılan kişi ${ }^{81}$ bu dönemde devletin yakın takibi sonucu çok fazla faaliyet alanı bulamadı. Ancak, sürgün olarak gönderildiği yerlerde ve hapishanelerde kaleme aldığı Risalelerle bağlılarına ulaşmayı başardı ve geniş bir halk kitlesini etkisine aldı. Kendilerine Nur talebeleri, Nur şakirtleri adını veren bağlıları bu dönemde çok hummalı bir çabaya girişerek risaleleri geniş bir halk tabanına ulaştırmayı başardılar. Said-i Nursi'nin kendi ifadelerinde hedeflediği kitleler hakkında bilgi edinmek mümkündür: “Türkiye'de yarım milyon şakirdim var (...) Bilhassa üniversiteli gençlerden şakirt kazanmak istiyorum". ${ }^{82}$ Bu haliyle Nurculuk Millî Şef yönetiminin en çok takip altına aldığı ve hareketlerine fazla müsaade etmediği bir akım olmuştur.

Cumhuriyet ilk döneminde birçok kez hapis cezasına mahkûm olan Said-i Nursi ve arkadaşlarının ikinci mahkûmiyetleri de İkinci Dünya Savaşı yıllarında oldu. 1934 yılındaki Eskişehir mahkûmiyetinden sonra Said-i Nursi, 1936 yılında Kastamonu'ya sürüldü. İkinci Dünya Savaşı başladığında Kastamonu'da sürgün tutulan Said-i Nursi bir karakolun tam karşısındaki bir evde 8 yıl göz hapsinde tutuldu. Burada Nursi'yi ziyarete gelenlerde sıkı takip ve kontrol altına alınıyordu. Bu arada Afyon ve Isparta'da yeniden tutuklamalar başladı. Kastamonu'da ise birkaç polis ve jandarma 31 Ağustos 1943 günü, Bediüzzaman'ın Araba Pazarı semtindeki evinde arama yaptılar. 18 Eylül 1943 tarihinde evi tekrar arandı. Said Nursi 20 Eylülde tutuklanarak polis nezaretinde Çankırı yoluyla Ankara'ya getirildi. Ankara'dan Isparta'ya, oradan da Denizli hapishanesine sevkedildi. Hakkında tekrar dava açılıp, Isparta, Kastamonu ve diğer muhtelif

${ }^{81} 1873$ yılında Bitlis'in Hızan ilçesi Nurs köyünde doğan Bediüzzaman Said-i Nursi, çeşitli medreselerde eğitim görmüştür. Van'da fen ve İslam bilimlerinin birlikte okutulacağı Medresetü'l Zehra'yı kurmak hayaliyle İstanbul'a gelmiş, Abdülhamit'le görüşmüş, İttihad-1 Muhammedi Fırkası'nı kuranlar arasında bulunmuş, ismi 31 Mart ayaklanmasına karışmış, İttihat ve Terakki'nin yaptıklarına sert elestiriler getirmis, bu nedenlerle Örf-i İdare mahkemesinde yargılanmıştır. Osmanlıların Birinci Dünya Savaşı'nda yenilmesi üzerine, Ankara'nın padişahı ve halifeyi kurtaracağı umuduyla Ankara Hükümeti lehine yazılar yazmıs, İstanbul Hükümeti'ni dini açıdan Ankara Hükümeti'ne karşı çıktığı için eleștirmis ve İslamiyet'e karşı gelmekle suçlamıştır. Said-i Nursi, daha sonra Ankara'ya gelip Mustafa Kemal ile görüşmüş, ancak onun halifeyi kurtarmak gibi bir niyeti olmayıp laik bir düşünceye sahip olduğunu anlayınca Van'a gidip oraya yerleșmiștir. Van'da Risale-i Nur'ları yazmaya başlayan Said-i Nursi, Şeyh Sait isyanından sonra hükümetçe Barla'da 'ikamete memur' edilmiş, oradan Kastamonu'ya ve daha sonra da Emirdağı'na sürülmüștür. Hayatının son yıllarını İsparta'da geçiren, 1954 ve 1957 seçimlerinde Demokrat Parti iktidarını destekleyen Said-i Nursi, 27 Mayıs ihtilâlinden kısa bir süre önce İ́stanbul ve Ankara üzerinden başlayan bir yurt gezisine çıkmış, 1960 yılında Urfa'da bir otel odasında 83 yaşında ölmüştür. Bkz.: Soysal, a.g.m., s. 1369

${ }^{82}$ Soysal, a.g.m., s. 1368 
beldelerden toplanan 126 talebesiyle birlikte Denizli A $\breve{g} ı$ Ceza Mahkemesine sevkedilen Said-i Nursi'ye isnat edilen suç, "gizli cemiyet kurmak, halkı rejim aleyhine tahrik etmek, İnkılâpları temelinden yıkma teşebbüsü, Mustafa Kemal hakkında 'Deccal' ve 'Din Yıkıcısı' gibi tabirler kullanmak" ${ }^{83}$ tı. Mahkeme, Risale-i Nur Külliyatında siyasi bir mevzu olup olmadı̆̆ını tetkik için İlahiyat Fakültesi profesörleri ve din âlimlerinden oluşan bir heyet tarafından incelenmesine karar verdi. Bu heyetin verdiği raporda, Said Nursi'nin siyasi bir faaliyeti olmadığı ve eserlerinin bir Kur'an tefsiri olduğu belirtilmesi üzerine, mahkeme 15 Haziran 1944 tarihinde beraat kararı verdi. Yaklaşık dokuz ay hapiste kalan Said Nursi ve talebelerinden bir kısmı, beraat kararı üzerine tahliye edildi. Ancak Said Nursi Denizli'de iki ay kaldıktan sonra, Afyon'un Emirdağ kazasında ikamete mecbur edildi ve Ağustos 1944'te devamlı gözetim altında tutulduğu bir eve yerleşti. Said Nursi'nin takip ve mahkûmiyetleri İkinci Dünya Savaşı sonrası yıllarda da devam edip birkaç defa daha hapis ve sürgün cezasına çarptırıldı.

Nurculuk gibi bu dönemde örgütlenme aşamasını yaşayan ve sıkı bir takip altında olan bir diğer İslamcı hareket ise Süleymancılıktı. Çocuklara ve gençlere Kur'an öğretmeyi faaliyet alanı olarak seçen ve kadrolaşmaya büyük önem veren Süleymancılık, tespit ettiği ekonomik ve politik amaçlar doğrultusunda faaliyet yürüten bir akımdır. Yoğun olarak açtıkları Kur'an kursları vasıtasıyla faaliyetlerini sürdüren bu akım mensupları, Arapça eğitim ve Kur'an-ı Kerim öğretiminin ardından rabıta esasına dayalı bir tarikat eğitimi yapmaktadırlar. Bu akımın kurucusu Silistreli Süleyman Hilmi Tunahan'dır. ${ }^{84}$

Süleyman Hilmi 1939 y1lında laiklik aleyhinde propaganda yapmaktan mahkemeye çıkarıldı, ancak beraat etti. Tunahan'ın ilk tevkif edilmesi 1943 yılında oldu. Tunahan ve arkadaşları laikliğe aykırı faaliyetlerinden dolayı

${ }^{83}$ Necip Fazıl Kısakürek, Son Devrin Din Mazlumları, Büyük Doğu Yayınları, İstanbul, 1997 , s. 229.

${ }_{84}$ Tunahan, 1888 yılında Bulgaristan'da Silistre'ye bağlı Varatlar köyünde dünyaya geldi. Babası Osman Fevzi Efendi'dir ve Silistre Hacı Ahmet Paşa Medresesi müderrisidir. Köyündeki ilk medrese eğitiminden sonra 1908 yılında İstanbul'a gelen Tunahan burada medrese eğitimini tamamlayarak, dersiam olarak Türkçe ve Arapça dersleri vermeye başladı. 1924'te Tevhid-i Tedrisat Kanunu'nun çıkmasından sonra açıkta kalan Süleyman Hilmi, bir süre ticaretle meşgul oldu, 1924-30 yılları arasında da muhtelif işlerde çalıştı.1930 yılından sonra İstanbul Müftülüğü'ne başvurup görev isteyen Süleyman Hilmi, Softa Hatip Camii vaizliğine atandı. Bu arada çeşitli şeyhlerle tanıştı ve sonradan dünürü olacak Halil Kaçar'ın Şehzadebaşı'ndaki köşkünün bir katını tekke haline getirdi. Beri yandan, cami kürsülerinde politik yanı ağır basan vaazlar veren Süleyman Hilmi, 1943 yılında vaizlik belgesi geri alındı. Yeniden ticaretle uğrassmaya başlayan Tunahan 1950'de DP iktidara gelince vaizlik belgesini yeniden elde ederek, Kur'an Kursları açmaya başladı, İmam-Hatip Kurslarına karşı da bir kavga başlattı, üç ayda müftü ve vaiz yetiştirilebileceğini yaymaya başladı. 1957'deki Bursa Ulucami olayından sonra damadı Kemal Kaçar ve Altıntaş Müftüsü Demirci Hoca ile hapse atılan Tunahan'ın DP ile ilişkileri bozuldu. 16 Eylül 1959'da vefat edince yerine damadı Kemal Kaçar geçti. Bkz. Soysal, a.g.m., s. 1371. 
yakınlarıyla birlikte İstanbul Birinci Şube Müdürlüğünde sorguya alındılar. Üç gün devam eden sorguları sırasında tabutluk denilen sorgu odalarında tutulan Tunahan ve yakınları, Birinci A ğır Ceza Mahkemesince suçsuz bulunarak beraat ettiler. Tunahan ve arkadaşları 1944 yılında tekrar aynı suçlamalarla tabutluklarda sorguya alındılar ve yine mahkeme tarafından beraat ettirildiler.

1943 yılında tutuklanan bir diğer kişi ise Nakşibendî Tarikatı şeyhlerinden Abdülhakim Arvasi'dir. Örfi İdare emriyle Eyüp Camii yakınlarındaki dergâhından alınarak, İstanbul Emniyet Müdürlüğü Birinci Şubeye götürülen Arvasi'nin, İstanbul dışına sürgün edilmesine karar verildi. Arvasi İzmir'e, beraberindeki 24 kişi muhtelif yerlere sürgün edildi. Arvasi bir müddet Meserret otelinde, sonra da bir evde polis nezaretinde kaldı. Bir süre sonra Ankara'ya nakledilen Arvasi, 27 Kasım 1943 tarihinde orada vefat ederek Bağlum ilçesine defnedildi. ${ }^{85}$

Millî Şef Yönetimini en çok uğraştıran bir diğer dini grup ise Ticani tarikatına mensup kişilerdi ${ }^{86}$ Kemal Pilavoğlu ${ }^{87}$ adında birinin yönettiği bu tarikat mensupları ellerine geçirdikleri çekiçlerle Atatürk heykellerine saldırıyor, huzursuzluk çıkartıyorlardı. Pilavoğlu ilk kez 1943'de, tarikat faaliyetleri suçundan 24 müridiyle beraber mahkemeye verildi ise de, kısa bir süre sonra serbest bırakıldı. Ancak Cumhuriyet'in laiklik prensibini reddeden, Türkiye'de İslami bir yönetim kurma düşüncesi taşıyan ve Atatürk'ün tüm devrimlerine karşı çıkan Ticaniler, 1946'da çok partili döneme geçişle birlikte güç kazanan dinsel bir hareket haline geldi. Ancak Ticani tarikatı asıl varlığını 1949 yılında Ankara ve çevresinde, Kur'an tarafından yasaklanmış olduğunu iddia ettikleri heykelleri, özellikle de Atatürk heykellerini kırmaya başlayarak hissettirdiler. "Heykel puttur", "laiklik dinsizliktir", "Hilafeti kaldıran Atatürk mel'undur", "Türkçe ezan

\footnotetext{
${ }^{85}$ Kisakürek, a.g.e., s. 322.

${ }^{86}$ Ticanilik adını, Şazeli-Halveti kökenli Ebu'l-Abbas Ahmed b. Muhammed el-Ticanî (1737-1815) tarafından 1740'larda Cezayir in güney kesiminde kurulan ve Fas, Hicaz, Mısır, Trablusgarp ve Senegal'de yayılan Ticaniye tarikatından alıyordu. Ticanilik, 'Tanrı emirlerini yerine getirip, Peygamberin ahlakını temsil etmek' iddiasındadır. Halveti tarikatının kollarından biridir. Sabah namazından kusluk vaktine kadar, ikindi namazından yatsıya kadar zikir gerektirir. Güya rüyasında Ahmed Et-Ticani ye intisap ettiğini gören ve ardından Abdülkadir Medeni adlı birinden tarikat ruhsatı aldı ̆̆ını iddia eden Kemal Pilavoğlu'nun kurduğu tarikatın, gerçek Ticaniye tarikatıyla doğrudan bir alakası yoktur. Türkiye`deki Ticanilere, daha çok 1940'lı, ‘50’li yıllarda rastlanır.

${ }^{87}$ Kemal Pilavoğlu 1906 yılında Ankara'da doğdu. İlk, orta ve lise tahsilini de Ankara da tamamladı. Bilahare Hukuk Fakültesi'ne devam edip başarılı olmasına rağmen, mezun olamadan, yani son sınıfta iken okuldan ayrıldı. Pilavoğlu, 1940'lardan itibaren, doğup büyüdüğü yer olan Ankara ve çevresinde mürit toplayarak tarikat faaliyetlerine hiz vermeye başladı. Faaliyetini yoğunlaştırdığı belli başlı merkezlerden biri Ankara'nın Çubuk ilçesi, bir diğeri ise Çankırı'nın Şabanözü ilçesiydi. Onun bu tarzdaki açıklamasına, daha ziyade çevrede 'Deli' sıfatıyla anılan müvazenesiz bazı kimseler inanmıș ve ona canı pahasına bağlanmıştır. Çeşitli kereler yargılanan ve 27 Mayıs Darbesinden sonra Bozcaada'ya sürgün edilen Pilavoğlu, 1977 yılında hayatını kaybetmiştir.
} 
küfürdür" sloganları ile tekrar ortaya çıkan Ticaniler, Arapça ezan yasağını çiğnemeyi bir eylem biçimi olarak belirlemişlerdi. Bu olaylardan sonra Nisan 1950'de Pilavoğlu tutuklanıp yargılanmak üzere Ankara Adliyesine getirildiğinde binlerce müridi, 200 kadar polisin tedbir aldığ 1 Adliye Sarayı'nın çevresinde toplanarak gösteri yaptı. ${ }^{88}$ Nitekim 1951 Haziranı'ndan itibaren devrimler aleyhinde propaganda yapan ve Atatürk heykellerini tahrip eden Ticaniler tutuklanmaya başlandı. 24 Temmuz 1951 tarihinde 5816 sayılı Atatürk'ü Koruma Kanununun kabul edilmesinde, Ticanilerin heykel kırma teşebbüslerinin büyük bir rolü oldu. Pilavoğlu ve 74 müridi, 5 Mart 1952'de Ankara 1. Ağır Ceza Mahkemesi'nde söz konusu kanuna muhalefetten 15 ay hapis cezasına mahkûm oldular. Kemal Pilavoğlu'nun mahkûm olması, sistemsiz bir irticai akım olan Ticaniliğin etkisini yitirmesine yol açtı.

\section{Ĕ̈itim, Külttür ve Yayın Alanlarında Laiklik Uygulamaları}

Eğitim, Atatürk döneminde olduğu gibi, bu dönemde de öncelikle kalkınma ve modernleşme problemi olarak ele alınmıştır. Atatürk döneminde kültür ve eğitim politikalarının ana eksenini laik ve millîyetçi bir çizgi oluştururken, İnönü döneminde laik-hümanist niteliği ağır basan politikalar uygulanmış, ancak millî anlayıştan da büsbütün uzaklaşılmamıştır. ${ }^{89} \mathrm{Bu}$ değişimin gerekçesi, gerçekten Batılılaşabilmek için Batı medeniyetini meydana getiren eski Yunan ve Latin kaynaklarına inilmesi gerektiği inancı olmuştur. 17-19 Temmuz 1939'da toplanan Birinci Maarif Şurası'nda konuşan Maarif Vekili Hasan Ali Yücel, liselerin müspet ilim zihniyetinin, millî kültürün ve millî kültür tekevvünü içinde hümanizm ruhunun hal ve istikbalini tayin edecek müesseseler olduğunu belirterek, pek çok ülkede ikinci yabancı dil olarak Latince ve Yunanca'nın öğrenildiğini ifade etti. ${ }^{90}$ Bu görüşler neticesinde 1940-41 öğretim yılı başından itibaren üç lisenin birinci sınıflarında 'klasik şube' açıldı. Bu şubelerde Latince ve daha ileriki sınıflarda ise Yunanca okutuldu. ${ }^{91}$ Eğitim için öngörülen ilke ve hedefler açısından İnönü'nün öğretmenlere hitaben söylediği şu sözleri anlamlıdır: "Sizin vereceğiniz terbiye dini değil millî, beynelmilel değil millîdir. Millî terbiye istiyoruz". ${ }^{92}$

İnönü kalkınmayı, ülkenin gelişmesini, bir ekonomik problemden çok bir kültür problemi olarak almıştır. Oluşturulacak yeni kültürle, Cumhuriyet

\footnotetext{
${ }^{88}$ Bernard Lewis, Modern Türkiye'nin Doğuşu, (çev. Metin Kıratlı), Türk Tarih Kurumu, Ankara, 2007, s. 415-416. 131.

${ }^{89}$ Cevdet Perin, Atatürk Kültür Devrimi, İnkılâp ve Aka Kitapevleri, İstanbul, 1982, s.

${ }^{90}$ Hasan Cicioğlu, Türkiye Cumhuriyeti'nde İlk ve Orta Öğretim (Tarihi Gelişim), AÜ EBF Yayınları, Ankara, 1985, s. 139.

${ }_{91}$ Cicioğlu, a.g.e., s. 141.

${ }^{2}$ İsmet İnönü’nün Maarife Ait Direktifleri, İstanbul Maarif Vekilliği Yayınları Maarif Matbaas1, Ankara, 1939, s. 4.
} 
ideolojisine gönül verecek ve rejimi koruyacak devrimci nesiller yetiştirilecekti. Bu nedenle, erkek çocuklarının yanı sıra kız çocuklarının da yeni açılan okullarda laik kültürle yetiştirilmesine özel bir önem verilmiş ve laik dünya görüşünün sosyal hayata yansıtılabilmesi için eğitimli ve modern düşünceye sahip kadınların artması hedeflenmiştir. Böyle olunca, köylere okul götürmek, konservatuar açmak, opera kurmak, devlet radyolarını Batı müziğine tahsis etmek, Millî Eğitim Bakanlığı yayınlarıyla 'Batı Kültürü'nü Türkçe'ye aktarmak gibi bir takım girişimler başlatılmıştır. O yılarda başlatılan tercüme faaliyetleri ile Arapça ve Farsça'nın dışlanması ile doğan boşluğu Yunanca ve Latince eserlerle doldurma çabası öne çıkmıştır. Bu çabaların geleneksel kültürle tıkanmaması için de laiklik son derece titizlikle uygulanmıştır. $\mathrm{Bu}$ uygulamalar o dönemde sağcı kesimin tepkisine yol açmıştır. 15 Aralık 1942 tarihinde Türk Yurdu Dergisinde yayınlanan bir yazıda "Biz hümanist veya komünist değiliz, Müslüman Türkleriz"93, 31 Temmuz 1943 tarihli Çınaraltı dergisinde de "din halkın afyonudur ilkesi Türkiye'de geçerli değildir" "ş şeklinde tepki gösterilmiştir.

Diğer taraftan eğitim yoluyla laikleştirme politikası, Atatürk zamanında kurulan Halkevleri vasıtasıyla yurdun en ücra köşelerine ulaştırılmaya çalışılmıştır. Halkın, devrime rağmen Ortaçağ uykusunu sürdürmesi; aydın ve halk kopukluğu; devrimin öncü kadroları ile halk, köy ile kent arasında bağ kurulması gerekliliği ve diğer toplumsal sorunlar, Cumhuriyet'in kuruluşundan bu yana yokluğu duyulan yeni bir halk örgütlenmesi gibi nedenlerle ortaya çıkan Halkevleri, ${ }^{95}$ devrimi yaygınlaştıracak ve halka indirgenmesini sağlayacak, dönemin en parlak kurumları olarak ön plâna çıkmışlardı. ${ }^{96} \mathrm{Bu}$ çerçevede, sosyal devrimleri benimsetmek ve çağdaşlaşmayı sağlayacak kültürel ve sanatsal etkinlikleri yürütmek, aydınların denetimi ve gözetiminde sanata, edebiyata ve araştırmaya eğilimli gençleri Atatürkçü görüş ve düşünce doğrultusunda yetiştirmek amacıyla

${ }^{93}$ Jaeschke, Türkiye Kronolojisi (1938-1945), s. 81. Benzer şekilde günümüzün İslamcı yazarları da, Yunan ve Batı Edebiyatına ait temel eserlerin tercüme edilmesini; dini atmosferin yaratılmasına ve gençlik için dini bir zihniyet fideliği vücuda getirilmesine taraftar olmayanların giriştikleri ve memleketi manevi bir sıkıntıya sürükleyen bir faaliyet olarak tanımlanmakta, böylece dinsiz (mülhid), ateist ve materyalist Avrupalı birçok mütefekkirin, yetişen nesillere benimsetildiğini ileri sürmektedirler. Bkz. Albayrak, a.g.e., s. 39.

${ }^{94}$ Jaeschke, Türkiye Kronolojisi (1938-1945), s. 89.

${ }_{95}$ Anıl Çeçen, Atatürk’ün Kültü̈r Kurumu: Halkevleri, Cumhuriyet Kitapları, İstanbul, 2000, s. 75, 77, 91-92.

${ }_{96}^{6}$ Iş1 Çakan, Konuşunuz Konuşturunuz - Tek-Parti Döneminde Propagandanın Etkin Silahı: Söz, Otopsi Yayınları, İstanbul, 2004, s. 82-89. Atatürk'ün 1 Ocak 1931'de İstanbul'da gazetecilerle yaptığı bir görüşmede Halkevlerinin kurulacağı yönündeki beyanatları üzerine çalışmalar başlatılmış ve 19 Şubat 1932 tarihinde ondört ilde Halkevlerinin açılışı yapılmıştır. 1932-1945 yilları arasında toplam 437 Halkevi ve 2718 Halkodası açılmıştır. Ancak çok partili düzene geçilmesiyle birlikte Halkevleri sarsılmaya başlamış ve 1951 yılından itibaren işlevsiz hale gelmişlerdir. Bkz. Eminalp Malkoç ve arkadaşları, "Kadıköy Halkevi ve Faaliyetleri: 1935-1951”, Yakın Dönem Türkiye Araştırmaları, İ.Ü. A.İ.I.T.E. Yayını, Yı1: 5/2006, Say1:10, s. 108-113. 
kurulan Halkevlerinin kütüphanelerinde dinle ilgili herhangi bir yayın bulunması yasaklandığı için ${ }^{97}$ dini bilgileri ve duyguları hatırlatacak, öğretecek bir faaliyetin olması söz konusu değildi.

Millî Şef döneminin en önemli projelerinden olan ve köyün her açıdan kalkınmasını, öğretim biçiminin geliştirilmesini ve bu amaca ulaşmaya yönelik eğiticilerin yetiştirilmesini hedefleyen Köy Enstitüleri, irticaya ve taassuba karşı yürütülen mücadelenin de mekânı olarak algılanmıştır. ${ }^{98}$ Yalnızca köylerden alınması plânlanan öğrenciler, kırsal kesimin koşulları ve sorunları ile pratik yaşamın gereklerine de önem verilerek, ancak pozitif aklın öğretileri doğrultusunda yetiştirilecektir. Hasanoğlan Köy Enstitüsü bünyesinde kurulan Köy Enstitüleri Dergisi'nde, yazmış olduğu bir makalede İsmail Hakkı Tonguç bunu şu şekilde dile getirmiştir: "Ümid edelim ki, yarının dünyası imanını göklerden gelecek görünmez kuvvetlerle ve fizik ötesi fikirlerle beslemesin. Eğer onun kuvvetli ve mesut bir temeli olsun istiyorsak biz insanlar yeni dünyaya şamil, ihtirassız, yalansız, insani, rasyonel ve reel taze bir din vermeliyiz. Köy Enstitüleri'nde yetiştirilen çocuklar, skolastiğe köle olmaktan kurtarılmaya çalışılmıştır." Sag "Sabattin Eyüboğlu'nun sözlerinde de bu hedefi görmek mümkündür: "Din ahlâk1 yerine iş ve bilim ahlâkını getirmek, kelimenin tam anlamıyla laik bir eğitimi gerçekleştirmek, kurucuların ana ilkelerinden biriydi. Türlü ırk, inanç, dil ve geleneklerin kaynaştığı, çatıştığı Anadolu'da laiklik sadece çağdaş düşünüşe ulaşmak değil, bir millet olarak yaşamanın da şartıydı. Her bölgenin özelliklerine uyan köy enstitülerinde iş saygısı ortak bir yeni din gibiydi."100 Bu nedenle Köy Enstitüleri'nin müfredatına bakıldığında din dersine hiç yer verilmediği görülür. Tonguç’un ifadesiyle, köyün önderi durumuna gelen öğretmen "devrimin bütün dinamizmasını yükleniyor, sarıklı köy hocasının yerini almaya çalışıyordu." ${ }^{101} \mathrm{Bu}$ sözler nasıl bir öğretmen tipi yetiştirilmek istendiğine dair önemli bir ipucu vermektedir.

1940 yılında kırsal kesimin kısa sürede kalkınması ve bunu sağlayacak elemanların kısa zamanda yetiştirilmesi amacıyla başlatılan bu proje kamuoyunda uzun süre tartışmalara neden olmuş, çok partili dönemde muhalefetin sert tepkisiyle karşılaşmıştır. 1954 yılında ilköğretmen okulları

${ }^{97}$ C.H.P. Halkevleri Talimatnamesi, Üçüncü Baskı, Ankara, 1934, s. 18; Türker Alkan, Siyasal Bilinç ve Toplumsal Değişim, Gündoğan Yayınları, Ankara, 1989, s. 183.

${ }_{98}$ Bir yandan eğitim alanında Halkevleri ve Köy Enstitüleri vasitasıyla laik bir nesil oluşturulmaya çalışılırken, diğer taraftan 1 Şubat 1941 tarihinde İstanbul Üniversitesinde İslam Araştırmaları Enstitüsü kapatıldı. Bkz. Jaeschke, Türkiye Kronolojisi (1938-1945), s. 68. 32.

${ }^{99}$ Mehmet Başaran, Köy Enstitüleri, 3. Baskı, Cumhuriyet Kitapları, İstanbul, 2003, s.

${ }^{100}$ Sabahattin Eyüboğlu, Köy Enstitüleri Üzerine, Yeni Gün Haber Ajans Basın ve Yayınc1lık, İstanbul, 1999, s. 76.

${ }^{101}$ İsmail Hakkı Tonguç, Canlandırılacak Köy, Remzi Kitabevi, İstanbul, 1947, s. 419. 
biçiminde düzenlenerek varlıklarını yitiren ${ }^{102}$ Köy Enstitüleri, 27 Ocak 1954 tarihinde Demokrat Parti iktidarı tarafından tamamen kapatıldı. Böylece aslında dar bir kadroya dayanan girişim, tek-parti dönemi dışındaki koşullarda ilerleme olanağını yitirmiştir. Çok sayıda öğretmen ve eğitmen yetiştirmenin ve köy çocuklarına öğrenim olanakları sağlamanın yanı sıra, Türkiye'nin kültür yaşamına damgasını vuran, bir köy kökenli aydın kuşağı yaratan Köy Enstitüleri, savaşa, uygulanan savaş ekonomisine karşın büyük değişimin yaratıcısı olmuştur. ${ }^{103}$ Enstitüler ayrıca, köyün ve köylünün sorunlarını da gündeme getirmeyi başarmıştır. ${ }^{104}$ Nihayet, Köy Enstitüleri deneyimi, evrensel eğitim düşüncesi yanında, Türkiye gerçeğini de dikkate alan özgün bir öğretmen yetiştirme örneği olarak eğitim tarihteki yerini almıştır. ${ }^{105}$

Eğitim ve kültür hayatındaki bu girişimlerin yanı sıra Millı̂ Şef döneminde ülkenin laik yapısına ve millî bir devlete aykırı olan, geçmişe dönüşü amaçlayan oluşum ve bunlara destek veren, inkılâplara muhalefet edici ve dini propaganda yapan yayınlara ve kitaplara çeşitli tarihlerde yasak getirildiği de görülmektedir. ${ }^{106}$ Örneğin, 1938'de 3, 1939'da 1, 1944'te 2 ve 1945'de 3 olmak üzere dini propaganda yapan (9) yayın ile 1938'de inkılâp aleyhtarı 1 yayına yasak getirilmiştir. Bu bağlamda İstanbul'da basılan ve İsmail Nazım Ergenel tarafından yazılan En'ami Şerif adlı broşür toplattırılmıştır. ${ }^{107}$ Yine aynı konuda İstanbul'da Mustafa Kocabaş tarafından yazılmış olan Din Klavuzu adlı eser, ${ }^{108}$ İman ve Amel adlı kitap, ${ }^{109}$ Ayet, Hadis ve ahlaki öğütleri içeren Arapça levhalar, ${ }^{110}$ Dua Mecmuası adlı broşür, ${ }^{111}$ Çocuklarımıza Din Okuma Kitabı adlı eser ${ }^{112}$ ve Tam ve İlaveli Mevlüdü Nebi adlı kitabın satışının yasaklandığını görüyoruz. ${ }^{113}$ Ahmet Hamdi Akseki tarafından 1943 yılında "Peygamberimiz Hz. Muhammed" adlı bir kitap, Sebilürreşad yayını olarak bastırılıp piyasaya çıkarıldıktan sonra Dâhiliye Vekâleti tarafından sakıncalı bulunarak toplattırılmıştır. Bunun üzerine kitabın yazarı, toplattırılma sebebini

\footnotetext{
${ }^{102}$ Mustafa Çıkar, Hasan Ali Yücel ve Türk Kültür Reformu, Türkiye İş Bankası Kültür Yayınları, Ankara, 1998, s. 94.

${ }^{103}$ Hanife Kuru, "İkinci Dünya Savaşı yıllarında Türkiye'de Sosyo-Kültürel Atılımlar", T.C. Genel Kurmay Başkanlığ Altıncı Tarih Semineri Bildirileri -1: Íkinci Dünya Harbi ve Türkiye (20-22 Ekim 1997 İstanbul), Genel Kurmay Basımevi, 1998, Ankara, s. 497-498. s. 30 .

${ }^{104}$ Mehmet Bayrat, Köy Enstitüleri ve Köy Edebiyatı, ÖZ-GE Yayınları, Ankara, 2000,

${ }^{105}$ Niyazi Altunya, Köy Enstitüleri Sisteminin Düşünsel Temelleri, 3.b., Uygun Basımevi, Ístanbul, 2002, s. 53.

106 Bu dönemde yasaklanan dini yayınların alındığ 1 kaynak için bkz. Yılmaz, "Cumhuriyet Döneminde Bakanlar Kurulu Kararı İle Yasaklanan Yayınlar 1923-1945".

${ }^{107}$ BCA. 030.18.01.85.77.15.

${ }^{108}$ BCA. 030.18.01.85.97.17.

${ }^{109}$ BCA. 030.18.01.86.14.16.

${ }^{110}$ BCA. 030.18.01.105.28.20

${ }^{111}$ BCA. 030.18.01.107.80.3.

${ }^{112}$ BCA. 030.18.01.107.103.13.

${ }^{113}$ BCA. 030.18.01.108.43.9.
} 
öğrenmek üzere müracaatta bulunmuştur. Matbuat Umum Müdürü Vedat Nedim (Tör) imzasıyla gönderilen cevapta "Bizler her ne surette olursa olsun, memleket dahilinde dini neşriyat yapılarak, dini bir atmosfer yaratılmasına ve gençlik için dini bir zihniyet fideliği vücuda getirilmesine taraftar değiliz" denilmektedir. ${ }^{114}$ Benzer şekilde Necip Fazıl Kısakürek tarafından yayınlanan Büyük Doğu Dergisi, Mayıs 1944 tarihli sayısında “Allah'a itaat etmeyene itaat edilmez" hadisini kapak yapınca, hükümet, halkın yöneticiler aleyhine kışkırtıldığı gerekçesiyle dergiyi kapatmıştır.

Yönetim sadece İslami eserler konusunda hassas olmayıp, İstanbul'da 15. yüzyıl mistiklerinden Thomas A. Kempıs'tan, S. Nuri imzası ile tercüme edilen Imitation yahut Mesihe Uymak adlı kitabın satışını da yasaklamıştır. ${ }^{115}$

Millî Şef yönetimi gazetelerde de laiklik ilkesine zarar verebilecek yazı ve haber yayınlanmasına izin vermiyordu. Nitekim İkinci Dünya Savaşı sonlarına doğru gazetelerde bu tür haber ve yazıların çıkması üzerine, Matbuat Umum Müdürlügü̈'nce basına yönelik bir talimat hazırlanmıştır. Bu talimatta, gazetelerin son günlerdeki yayınlarında dinden bahseden yazı, mütalaa, ima ve temennilere rastlandı ̆̆ gerek tarihi, gerek temsili ve gerekse mütalaa kabilinden olan her türlü makale, bend, fıkra ve tefrikaların neşrinden tevakki edilmesi ve başlanmış bu kabil tefrikaların en çok üç gün zarfında nihayetlendirilmesi ehemmiyetle rica olunur" ${ }^{116}$ denilerek basına gerekli ikaz yapılmıştır.

Dini yayınlara getirilen bu yasaklamalara karşın, yönetimin 1939 yılında dini yayın alanında çok önemli bir adım atarak İslam Ansiklopedisini yayınlamaya karar verdiği görülmektedir. Bu Ansiklopedi'nin yayınlanması ile ilgili Lewis şunları söylemektedir: "Türk Millî Eğitim Bakanlığı Avrupalı şarkiyatçılardan kurulu uluslararası bir ekip tarafından Leiden'de yayınlanan büyük kolektif eser Encyclopedia of Islam (İslam Ansiklopedisi)ın Türkçe basımını yayınlamaya karar verdi. Türkçe basısı salt bir çeviriden ibaret değildi. Eskimiş olan birçok yazılar Türk bilim adamlarınca gözden geçirilecek veya yeniden yazılacak, birçok yazılar da eklenecekti; fakat tümü, Leiden basısına egemen olan aynı bilimsel zihniyet içinde kalmak amacındaydı. Dönemin İslamcı dergilerinden Sebil-ür Reşad'ın yayınlayıcısı olan Eşref Edip başta olmak üzere dindar zihniyette bir grup Türk, bu projeye şiddetle karşı çıktı." ${ }^{117}$ İslamcı yazarlar bunun misyonerler tarafından yazılmış, İslam dininin

${ }^{114}$ Sebilürreşad, C. XIII, Say1: 284, 1959, s. 144; Ali Fuat Başgil, Din ve Laiklik, Yağmur Yayınları, 6. Bask1, İstanbul, 1996, s. 16-17.

${ }^{115}$ BCA. 030.18.01.85.101.16.

${ }^{116}$ Suna Kili-Şeref Gözübüyük, Türk Anayasa Metinleri; Tanzimat'tan Günümüze Kadar, T. İş Bankası Yay., İstanbul, 1957, s. 125-126.

${ }^{117}$ Lewis, Modern Türkiye'nin Doğuşu, s. 412-413. Eşref Edip sonraki yıllarda da, yapılan uygulamaları daha ağır dille eleştirmeye devam etmiştir. "Onlar milleti hiçe saydılar. En mukaddes hislerine taarruzdan çekinmediler. Memleketin her tarafını sefalet ve ıstırap kapladı. Vicdanlara hançerler soktular. Ezanları değiştirdiler. Camilerin içlerine kadar 
temellerini yıkmayı amaçlayan ve misyonerlik hedefi güden İslam düşmanı bir ansiklopedi olduğunu ileri sürerek, 1941 yılında Türk-İslam Ansiklopedisi adında yeni bir ansiklopedi yayınlamaya başladılar. Çıkardıkları ansiklopedinin her fasikülünde, Bakanlıkça yayınlanan bütün ansiklopedilerin şiddetli tenkitlerini yaptılar. Lewis, 1940 yılında yaşanan bu gelişmeyi devletin laik politikasına karşı muhalefetin ilk açık belirtisi ${ }^{118}$ ve dini canlanmanın (inkişafın) ilk işareti olarak tanımlamaktadır. ${ }^{119}$ Bütün eleştirilere karşın Ansiklopedi'nin yayını devam etti ve 1950 yılına kadar beş cildin yayını gerçekleştirildi.

İslam Ansiklopedisi’nin yanı sıra İnönü döneminde 1945 yılına kadar 104 adet dini nitelikli kitap yayınlandığı görülmektedir. ${ }^{120} 1939$ yılında yayınlanan kitaplara A. Vecihi Uryani'nin askerlere yönelik kaleme aldığı Asker İlmihali, İslam tarihi yazarlarından M. Asım Köksal'ın Armağan, Prof. Dr. İsmail Baltacıoğlu'nun Din ve Hayat; 1940 yılında yayınlanan kitaplara Hasan Basri İlmihali, Namaz Sure ve Duaları, Y. Z. Balçıkoğlu'nun Tarihi-i Nur-i Muhammedi ve Veladet-i Cenabı Ahmedi; 1941 yılında yayınlanan kitaplara M. Selami Yurdatap'ın Binbir Hadis Tercümesi ve Tefsiri, M. Asım Köksal'ın Peygamberler, Abdurrahim Zapsu'nun, Hale'nin Din Dersleri, İlaveli ve Musahhah Mızraklı İlmihal, A. Hamdi Akseki'nin Yavrularımıza Din Dersleri, 1942 yılında yayınlanan kitaplara Abdurrahim Zapsu'nun Oğlum Pertev'in Din Sorunları; 1943 yılında M. Şerafettin Yaltkaya'nın Benim Dinim, A. Hamdi Akseki'nin İslam, Fitri, Tabii ve Umumi Bir Dindir, Ö. Fevzi Mardin'in, Müslümanlık Esasları, 1944 yılında yayınlanan kitaplara A. Hamdi Akseki’nin Askere Din Kitabı, Eşref Edip'in Çocuklarımıza Din Okuma Kitabı, Muhammed Gazali'nin Hüccet'ül İslam, M. Akif Ersoy'un Kur'an'dan Ayetler, Mehmet Demir'in Tercümeli İman ve İbadet Dersleri, 1945 yilında yayınlanan kitaplara R. Halil İnanç'ın Akide-i İslam, Münif Çelebi'nin Kur'an Dili ve Okuma Kaideleri, M. Hamdi Erdem'in Esma'ül Hüsna yahut Tanrının Güzel İsimleri Şerhi örnek olarak verilebilir. ${ }^{121} \mathrm{Bu}$ dönemde dini propaganda yaptığı gerekçesi ile 9 yayına yasak getirilirken, 104 adet dini nitelikli kitap

tecavüzlerini uzattılar. İbadetlere müdahale ettiler. Din namına cemiyet teşkilini men ettiler. (...) Dini müessesleri kapattılar. Din ehlini zelil ettiler. Sefalet içinde inlettiler. Dilenecek hale getirdiler." Bkz. Essref Edip, "Hakka Arka Çevirenlerin Akıbeti", Sebilürreşad, C. IV, No. 78 , (Mayıs 1950), s. 35-36. Benzer bir eleştiriyi yapan Ali Fuat Başgil, Moskova'yı imrendirecek düzeyde bir din ve maneviyat düşmanlığı yapıldığını belirtmekte ve milletin CHP'ye ve tekparti yönetimine olan küskünlügüünün ve gücenikliğinin artmasında "halkın dinine ve mukaddesatına karşı” takınılan olumsuz tavrın rolü olduğunu söylemektedir. Bkz. Ali Fuat Başgil, "Çeyrek Asır Devam Eden Zulüm Devri", Sebilürreşad, C. IV, No. 85, (A ğustos 1950), s. 146.

${ }^{118}$ Lewis, Modern Türkiye'nin Doğuşu, s. 412.

119 Bernard Lewis, "Islamic Revival in Turkey", International Affairs, Vol. XXVIII, 1952 , s. 38-48.

${ }^{120} \mathrm{Bu}$ kitaplarının isimleri ve yıllara göre dağılımı için bkz. Ahmet Esenkaya, "İnönü Dönemi Laiklik Politikası (1938-1950)", (Basılmamış Yüksek Lisans Tezi, Hacettepe Üniversitesi Atatürk İlkeleri ve İnkılâp Tarihi Enstitüsü, Ankara, 1995), s. 141-145.

${ }^{121}$ Esenkaya, a.g.t., s. 141-145. 
yayınlanmış olması, yönetimin din düşmanlığı ile hareket etmediğini göstermesi bakımından anlamlıdır.

\section{SONUÇ}

Türkiye'de Millî Şef dönemi özellikle İkinci Dünya Savaşı'nın da etkisiyle sıkıntılı günlerin yaşandığı, her an savaşa dahil olma olasılığı ile, hem yönetim kademesinde hem de halk tabanında savaş ekonomisinin koşullarının tüm ağırlığıyla hissedildiği, halkın günlük yaşamında çektiği sıkıntıların doğrudan veya dolaylı olarak iç güvenlik olgusunu etkilediği bir dönem olmuştur.

Türkiye, İkinci Dünya Savaşının sonuna kadar bir denge politikası güderek savaşın dışında kalmayı başarmış ${ }^{122}$ ancak ülke içerisinde birçok ekonomik, sosyal ve siyasal sorunlar yaşanmıştır. Bunların yanı sıra Atatürk devrimlerinin korunması ve dine karşı gösterilecek hoşgörünün, politikaya yansıyabileceği endişesi, Millî Şef yönetiminin hiçbir zaman göz ardı etmediği olgular olmuştur. İnönü, ülkenin iç güvenliğini sağlama ve Atatürk Devrimlerini muhafaza konusunda tavizsiz bir politika benimsemiş, özellikle laiklik karşıtı en ufak bir oluşuma fırsat vermemiştir. Esenkaya'nın vurguladığ 1 gibi "Millî Şef döneminde inkılâplarla ilgili kanunlar, daha da şiddetlenerek uygulanmış, ayrıca ilk defa sayılabilecek yeni uygulamalara da geçilmiştir. İnönü dönemi laiklik politikasında görülen en büyük değişim, millîlik yerine hümanistleşme olmuştur. Eğitim ve kültür politikasında da hâkim olan bu görüş; dine hiçbir zaman taviz vermemiş, laiklik çok katı bir şekilde uygulanmıştır. Böylece İnönü, Atatürk'ten devraldığı laikleştirme mirasını daha da geliştirerek, bazen de sertleştirerek korumuş ve geliştirmiştir." 123

Bu tavır ve tavizsiz politikalar, ülkede siyasi, ideolojik ve dini akımların eylem sahasını daraltmıştır. Türkçe ezan uygulaması ve Arap harfleri ile çocuklara tedrisat yaptırılanların takibi konularında kolluk kuvvetlerine oldukça yoğun iş düşmüştür. Polis arşivlerinde bu konuda tutulmuş çok sayıda arşiv kaydına rastlamak mümkündür. Biraz da savaşın toplumsal yaşam üzerinde meydana getirdiği yıkıcı tesirle, laiklik aleyhtarı faaliyetler

${ }^{122}$ Türkiye'nin dış politikasını belirlerken savaşın dışında kalma hedefinin yanı sıra laiklik konusunda da duyarlı hareket ederek diğer ülkelerle olan ilişkilerini bu çerçevede yürütmeye çalıştı̆̆ 1 görülmektedir. Örneğin Millî Şef yönetimi ütopya olarak gördüğü İslam Birliği çalışmalarına katılmayı laiklik adına uygun bulmamıştır. Dünya İslam Kongresi’nin 1937'ye kadar aktif olmaması üzerine Kral Faruk, yeni bir birlik oluşturarak 1939'da hilafet meselesini tekrar gündeme getirdi. Çalışmalara davet edilen Türkiye buna iştirak etmedi. Bu yaklaşımın temel mantı̆̆ını, 1943 yllında bir Türk basın heyeti ile Hindistan'a giden Falih Rıfkı Atay'ın, Lahor'da yaptığı açıklamada görmek mümkündür: 'Yardımınızı hiçbir zaman unutmayacağız... Biz önce Türküz, sonra Müslümanız. Bizim herhangi bir İslam birliği projesi ile ilgimiz yok... Bizim için din saygideğer bir özel sorundur, fakat Türk siyasetinde hiçbir yeri yoktur,", Tasvir-i Efkâr (30 Ocak 1943); Jaeschke Türkiye Kronolojisi (1938-1945), s. 82.

${ }^{\mathrm{i} 23}$ Esenkaya, a.g.t., s. 134. 
hız kesmiş gibi gözükse de, bu dönemde birçok siyasi hareketlenmelerin -çoğu zaman gizlice- yoğun olarak yaşandığ gözlemlenebilir. Resmi polis raporları ve yazışmaları incelendiğinde, faaliyetlerini gizli gizli devam ettiren bazı tekke, zaviye ve tarikatların, yine bu dönemde polis tarafından sıkı bir şekilde takip edildiği görülmektedir.

Bu uygulamaların özellikle sonraki dönemleri de etkilemesi açısından birçok önemli sonuçları olmuştur. Yeni sosyal düzende de görülen ve artarak devam eden eşitsizliklerin ve adaletsizliklerin, toplumda yükselen beklentileri gerçekleştirememesi neticesinde, bilinen tek ideolojinin, halk tarafından geliştirilen İslami yoruma dönüştürüldüğünü ileri süren Mardin'e göre ${ }^{124}$ Türkiye'de, 1940'lardan itibaren volk (halk) İslama dönüş isteği belirmiştir. Bu durumla ilgili olarak Türköne şu yorumu yapmaktadır: "Ezanın Türkçeleşmesinde sembolleşen dini yerleştirme ve dini laikleştirme teşebbüsleri, İslamiyet'in tabiatına uymadığı ölçüde, halk İslamının daha da içine kapanmasına ve dinin muhafazakâr formlarının güçlenmesine yol açmıştır." 125

Bu dönemde yapılan laiklik uygulamalarının bir diğer önemli sonucu, savaştan sonra kurulan çok partili hayatta farklı bir oluşumu meydana çıkarması, İslami faaliyetlerde gözle görünür bir artış ${ }^{126}$ olmasıdır. Millı̂ Şef döneminde yeraltına inmiş bulunan İslami hareketler, 1946'da tek parti yönetiminin sona ermesinden sonra çok daha yumuşamış olarak yeniden su yüzüne çıkmıştır. ${ }^{127}$ Lewis, Türkiye'nin savaş sonrası yeni demokrasisinin, tabiatıyla artık laikliğe karşı düşmanlıklarını ve İslamlığın ihyası isteklerini gittikçe daha açık olarak ilan eden dini liderler de dahil olmak üzere, bütün fikir akımlarına çok daha büyük bir ifade hürriyeti verdiğini söylemektedir. ${ }^{128}$ Özellikle katılımcı ve yarışmacı bir siyasi hayata geçerken bu istekler önem kazanmış, ağırlıklı faktör haline gelmiştir.

Millî Şef döneminde izlenen din ve laiklik politikaları, çok partili hayatın başlamasıyla birlikte muhaliflerin ve özellikle DP'lilerin CHP aleyhinde kullandıkları bir propaganda konusu olmuştur. Akandere'ye göre geniş halk kesimlerinin Terakkiperver Fırka ve Serbest Cumhuriyet Fırkası denemelerinde olduğu gibi CHP'ye muhalif olarak kurulan DP'yi 1994, s. 33

${ }^{124}$ Şerif Mardin, Din ve İdeoloji, İletişim Yayınları, İstanbul, 1995, s. 143-156.

${ }^{225}$ Mümtaz'er Türköne, Modernleşme, Laiklik ve Demokrasi, Ark Yayınevi, Ankara,

${ }_{126}$ Lewis, Modern Türkiye'nin Doğusu, s. 413-420. 1947 yılında İçisleri Bakanı Sükrü Sökmensüer imzasıyla tüm Genel Müfettişliklere ve Valiliklere gönderilen bir yazıda, son yıllarda irtica olaylarının gittikçe arttığı ve 1946 yılındaki gerileme çabalayışlarında, bir önceki yıla nazaran \% 80 nispetinde bir artış olduğu belirtilmektedir. Bkz. 150likler, Kubilay Olayı, Çarşaf-Peçe-Peştemalla Örtünme Sorunlart, 25.8.1947 tarihli ve 13311-19/2 sayllı genelge, s. 98.

${ }_{127}$ Binnaz Toprak, "Dinci Sağ”, içinde Geçis Sürecinde Türkiye, (Der. İrvin Cemil Schick ve E. Ahmet Tonak), Belge Yayınları, İstanbul, 1992, s. 247.

${ }^{128}$ Lewis, Modern Türkiye'nin Doğuşu, s. 413. 
desteklemelerinin altında, tek parti yönetimlerinin dini müesseselere ve din çevrelerine karşı takındığı tutum ve uygulamaları olmuştur. ${ }^{129}$ Ancak çokpartili dönemde oluşan muhalefetin ve İnönü aleyhinde kamuoyunda oluşan tepkinin tek sebebini, sadece laiklik uygulamalarına bağlamak yanlış olur. Hemen her alanda ülkede yıkıcı bir tesiri olan İkinci Dünya Savaşı'nın getirdiği sosyal adaletsizlik, savaş sıkıntıları ve uygulanan ekonomik politikalardan dolayı Tek Parti yönetimine karşı hoşnutsuzluğun $\operatorname{arttığ1}{ }^{130}$ ve sonradan gelecek çok partili hayatta büyük bir oranda muhalefete destek verecek bir oluşumun temellerinin atıldığını söylemek mümkündür.

$\mathrm{Bu}$ dönemde incelediğimiz laiklik uygulamalarının, din düşmanlığı, Türkiye'yi İslam'dan koparma ve Çaha'nın ileri sürdüğü "kamusal alanı dini değerlerden, toplumu da dini simgelerden arındırma, dinin etkisini azaltmak için onun üzerinde mutlak anlamda kontrol ve denetim sağlama"131 gibi amaçlarla gerçekleştirildiğini ileri sürmek sağlıklı bir değerlendirme değildir. Millî Şef yönetiminin, bu uygulamalarda öncelikli kaygısı Atatürk Devrimlerinin yaşatılması ve kökleştirilmesidir. $\mathrm{Bu}$ nedenle yapılan uygulamalarda salt bir din düşmanlığından öte, İkinci Dünya Savaşı'nın yol açtığı olumsuz şartların da etkisi ile hareket edildiğini göz önünde bulundurmak gerekir. Tarihte yaşanmış her olguyu kendi zaman ve koşulları içerisinde değerlendirmek gerektiği gerçeğinden hareketle, bu uygulamaları da o dönemin koşulları içinde değerlendirmek gerekir. Her an savaşa girme tehlikesi yaşayan Türkiye'nin, meydana gelecek bir iç güvenlik sorunu ile uğraşmamak ve tüm enerjisini iç güvenlik yerine dışarıdan gelebilecek bir saldırıya karşı yoğunlaştırmak için bu tür tavizsiz ve sert uygulamalara gidildiğini söylemek mümkündür. Nitekim Karpat'nn şu değerlendirmesi düşüncemizi desteklemesi açısından anlamlıdır: “Türkiye'nin çağdaş bir devlet haline gelebilmesi ancak laikliğin kabulü ile mümkün olabilirdi: 1930'lu ve 1940'lı y1llarda din üzerine konan tahditlerin sebebi dine karşı içten içe beslenen bir düşmanlık değildi. İslamiyet'i kontrol altında tutmak ve reformların toplumda kökleşmesine imkân vermek için duyulan acil ihtiyaçtan doğmuştu. Sadece bu ciddi ve sert tedbirler sayesindedir ki cumhuriyet nispeten sağlam laik temeller üzerine oturtulabilmiştir." ${ }^{132}$.

${ }^{129}$ Akandere, a.g.e., s. 242. Aynı yöndeki görüş ve değerlendirmeler için bkz. Lewis, Modern Türkiye'nin Doğuşu, s. 411-420. Çok partili dönemle birlikte başlayan laiklik tartışmaları sadece o yıllarla sınırlı kalmamış günümüze kadar devam edegelmiştir. İslami hareketlerin "devlet kontrolü altına alınması ve bunun bir gereği olarak bireysel özgürlüklerin kısıtlanması, söz gelimi çeşitli tarikatların faaliyetlerinin yasaklanması, 1946'dan bu yana sürekli tartışma konusu olmuştur." Bkz. Toprak, "Dinci Sağ", a.g.m., s. 247.

${ }_{130}$ Eroğul, "Çok Partili Düzenin Kuruluşu: 1945-71”, s. 113; Murat Belge, "Türkiye’de Günlük Hayat", Cumhuriyet Dönemi Türkiye Ansiklopedisi, Cilt: III, İletişim Yayınları, İstanbul, 1983, s. 846

${ }^{131}$ Ömer Çaha, "Türkiye'de Resmi Din Anlayışı: Etatokratik Sistemin İnşası”, Islamiyat, Vol. IV, No. 4, Jan. 2001, s. 77-89.

${ }^{132}$ Kemal H. Karpat, Türk Demokrasi Tarihi: Sosyal, Ekonomik, Kültürel Temelleri, Afa Yayınc1lı, İstanbul, 1996, s. 236. 


\section{KAYNAKÇA}

“Ezan 18 y1l Türkçe okundu”, Hürriyet (16.6.2000).

"Meclis’te garip bir vaka. İki adam bağıra bağıra Arapça ezan okumaya başladılar." Hürriyet (05.02.1949)

150likler, Kubilay Olayı, Çarşaf-Peçe-Peştemalla Örtünme Sorunları: Polis Arşiv Belgeleriyle Gerçekler, Polis Dergisi, Yayın No: 129, EGM Yayınları, Ankara, 1998.

Akandere, Osman: Millî Şef Dönemi: Çok Partili Hayata Geçişte Rol Oynayan İç ve Dış Tesirler (1938-1945), İz Yayıncılık, İstanbul, 1998.

Akşam (1.3.1933).

Albayrak, Sadık: Türkiye’de Din Kavgası, Şamil Yayınevi, İstanbul, 1984.

Alkan, Türker: Siyasal Bilinç ve Toplumsal Değişim, Gündoğan Yayınları, Ankara, 1989.

Altunya, Niyazi: Köy Enstitüleri Sisteminin Düşünsel Temelleri, 3.b., Uygun Basımevi, İstanbul, 2002.

Alyot, Halim: Türkiye'de Zabıta, Tarihi Gelişim ve Bugünkü Durum, Kanaat Basımevi, Ankara, 1947.

Aydemir, Şevket Süreyya: Íkinci Adam, Cilt: II, Remzi Kitabevi, İstanbul, 1991.

Başaran, Mehmet: Köy Enstitüleri, 3. Baskı, Cumhuriyet Kitapları, İstanbul, 2003

Başbakanlık Cumhuriyet Arşivleri, [BCA]. Dosya: 86-395, Yer No: 4.36..15; 030.18.01.105.28.20; $\quad 030.18 .01 .107 .103 .13 ; \quad 030.18 .01 .107 .80 .3$; 030.18.01.108.43.9; $\quad 030.18 .01 .85 .101 .16 ; \quad 030.18 .01 .85 .77 .15$; 030.18.01.85.97.17; 030.18.01.86.14.16.

Başgil, Ali Fuat: “Çeyrek Asır Devam Eden Zulüm Devri”, Sebilürreşad, C. IV, No. 85, (A ğustos 1950).

Başgil, Ali Fuat: Din ve Laiklik, Yağmur Yayınları, 6. Baskı, İstanbul, 1996.

Bayrat, Mehmet: Köy Enstitüleri ve Köy Edebiyatı, ÖZ-GE Yayınları, Ankara, 2000.

Belge, Murat: “Türkiye'de Günlük Hayat”, Cumhuriyet Dönemi Türkiye Ansiklopedisi, Cilt: III, İletişim Yayınları, İstanbul, 1983, s. 836-860.

Bozdağ, İsmet: Zaferlerle ve Şereflerle Dolu Bir Hayat: Celal Bayar, Tercüman Yayınları, İstanbul, 1986.

C.H.P. Halkevleri Talimatnamesi, Üçüncü Baskı, Ankara, 1934. 
C.H.P. Programının Hükümetçe Tahakkuk Ettirilen Kısımları Hakkındaki Rapor, Ulus Matbaası, Ankara, 1939

Cicioğlu, Hasan: Türkiye Cumhuriyeti’nde Illk ve Orta Öğretim (Tarihi Gelişim), AÜ EBF Yayınları, Ankara, 1985.

Cumhuriyet (05.02.1949).

Cumhuriyet (31.02.1932).

Cumhuriyet Halk Partisi Üsnomal Büyük Kurultay’ın Zabtı, (26.12.1938), Recep Ulusoğlu Basımevi, Ankara, 1938.

Çaha, Ömer: “Türkiye'de Resmi Din Anlayışı: Etatokratik Sistemin İnşası”, Íslamiyat, Vol. IV, No. 4, Ocak 2001, s. 77-89.

Çakan, Işıl: Konuşunuz Konuşturunuz - Tek-Parti Döneminde Propagandanın Etkin Silahı: Söz, Otopsi Yayınları, İstanbul, 2004.

Çeçen, Anıl: Atatürk'ün Kültür Kurumu: Halkevleri, Cumhuriyet Kitapları, İstanbul, 2000 .

Çıkar, Mustafa: Hasan Ali Yücel ve Türk Kültür Reformu, Türkiye İş Bankası Kültür Yayınlar1, Ankara, 1998.

Daver, Bülent: Türkiye Cumhuriyeti'nde Laiklik, Siyasal Bilgiler Fakültesi Yayınlar1, Ankara, 1955.

Edip, Eşref: "Hakka Arka Çevirenlerin Akıbeti”, Sebilürreşad, C. IV, No. 78, (Mayıs 1950), s. 35-36.

Emniyet Genel Müdürlüğ̈̈ Arşivleri [EGMA, Ankara], D[osya]. 13217-11, K[ardeks]. 1964; D.13217-13, K.3109; D.13217-13, K.3109; D.11215-1, K.56857; D.13216-7; D.13217-3, K.596; D.13217-3, K.595; D.13217-5, K.597; D.13217-8, K.906; D.13217-12, K.287; D.13217-13, K.3109; D.13217-15，K.3118；D.13217-14，K.3119; D.13217-146，K.26563; D.13217-148, K.26602; D.13217-102, K.22892; D.13217-133，K.26572; D.13217-9, K.1999; D.13217-17, K.3111; D.13217-22, K.3394; D.13217-21, K.3395; D.13217-7, K.593; D.13217-111, K.23756; D.13217-118, K.24949; D.13217-17, K.3111; D.13217-50, K.26884; D.13217-147，K.26562; D.13219-122, K.29448; D.13219-107, K.27219; D.13219-103, K.26941; D.13219-132，K.35124; D.13219-140，K.38097; D.11215-1，K.56857; D.13219-145, K.39028; D.13219-143, K.38875; D.13219-144, K.390; D.13219-150, K.39880; Dosya No: 13219-138, K.37004; D.13219-24, K.896; D.13219-149, K.39409; D.13219-133, K.36252.

Eroğul, Cem: "Çok Partili Düzenin Kuruluşu: 1945-71”, içinde Geçiş Sürecinde Türkiye, (Der. İrvin Cemil Schick ve E. Ahmet Tonak), Belge Yayınları, İstanbul, 1992, s. 112-158. 
Esenkaya, Ahmet: "İnönü Dönemi Laiklik Politikası (1938-1950)", (Basılmamış Yüksek Lisans Tezi, Hacettepe Üniversitesi Atatürk İlkeleri ve İnkılap Tarihi Enstitüsü, Ankara, 1995).

Eyüboğlu, Sabahattin: Köy Enstitüleri Üzerine, Yeni Gün Haber Ajans Basın ve Yayıncılık, İstanbul, 1999.

Goloğlu, Mahmut: Millî Şef Dönemi (1939-1945), Kalite Matbaası, Ankara, 1974.

Gürtaş, Ahmet: Atatürk ve Din Eğitimi, DİB Yayınları, Ankara, 1982.

Hakikat Dergisi, Başyazı, Sayı: 109 (Ekim 2002), (Çevrimiçi), http://www.hakikat.com/dergi/109/bsyz10902.html, 11.04.2004.

İsmet İnönü'nün Maarife Ait Direktifleri, İstanbul Maarif Vekilliği Yayınları Maarif Matbaası, Ankara, 1939.

Jaeschke, Gotthard: Türkiye Kronolojisi (1938-1945), (Çev. Gülayşe Koçak), Türk Tarih Kurumu Basımevi, Ankara, 1990.

Jaeschke, Gotthard: Yeni Türkiye'de İslamcıllk, (çev. Hayrullah Örs), Bilgi Yayınevi, Ankara, 1972.

Kader (05.02.1949).

Karpat, Kemal H.: Türk Demokrasi Tarihi: Sosyal, Ekonomik, Kültürel Temelleri, Afa Yayıncılık, İstanbul, 1996.

Kısakürek, Necip Fazıl: Son Devrin Din Mazlumları, Büyük Doğu Yayınları, İstanbul, 1997.

Kili, Suna -Şeref Gözübüyük: Türk Anayasa Metinleri; Tanzimat'tan Günümüze Kadar, T. İş Bankası Yay., İstanbul, 1957.

Koçak, Cemil: "İkinci Dünya Savaşı ve Türk Basını", Tarih ve Toplum, Cilt: VI, Say1: 35 (Kasım 1986), s. 29-35.

Koçak, Cemil: "Siyasal Tarih (1923-1950)", içinde Türkiye Tarihi-4, Çă̆daş Türkiye: 1908-1980, (ed. Sina Akşin ve diğerleri), Cilt: IV, Cem Yayınevi, İstanbul, 2000, s. 127-211.

Koçak, Cemil: Türkiye'de Millî Şef Dönemi (1938-1945), (Dönemin İç ve Dış Politikası Üzerine Bir Araştırma), Yurt Yayınları, Ankara, 1986.

Kuru, Hanife: "İkinci Dünya Savaşı yıllarında Türkiye'de Sosyo-Kültürel Atılımlar", T.C. Genel Kurmay Başkanlı̆̆g Altıncı Tarih Semineri Bildirileri -1: İkinci Dünya Harbi ve Türkiye (20-22 Ekim 1997 İstanbul), Genel Kurmay Basımevi, 1998, Ankara.

Lewis, Bernard: "Islamic Revival in Turkey", International Affairs, Vol. XXVIII, 1952, s. 38-48. 
Lewis, Bernard: Modern Türkiye'nin Doğuşu, (çev. Metin Kıratlı), Türk Tarih Kurumu, Ankara, 2007.

Malkoç, Eminalp ve arkadaşları: "Kadıköy Halkevi ve Faaliyetleri: 1935-1951", Yakın Dönem Türkiye Araştırmaları, İ.Ü. A.İ.I.T.E. Yayını, Yı1: 5/2006, Say1:10, s. 105-165.

Mango, Andrew: Türkiye ve Türkler: 1938'den Günümüze, Remzi Kitabevi, İstanbul, 2005.

Mardin, Şerif: Din ve İdeoloji, İletişim Yayınları, İstanbul, 1995.

Meriç, Cemil: Bu Ülke, İletişim Yayınları, İstanbul, 1994.

Milliyet (05.02.1949),

Orkun, Hüseyin Namık: "Nazmi Serim, İstihbarat-II: İç İstihbarat", Kitap incelemesi, Polis Dergisi, Y1l: 27, Say1: 14-325 (1 Mayıs 1941), s. 154-160.

Öymen, Altan: Değişim Yılları, Doğan Kitapçılık, İstanbul, 2004.

Perin, Cevdet: Atatürk Kültür Devrimi, İnkilap ve Aka Kitapevleri, İstanbul, 1982.

Pulur, Hasan: “Arapça ezan Türkçe ezan...”, Milliyet (2.12.2004)

Sadak, Necmettin: "Gençliği tarih, coğrafya ve siyasete ters düşen İslamcılık, Turancılık ve Irkçılığa karşı koruyalım.!” Akşam (17 Mayıs 1944).

Sebilürreşad, C. XIII, Sayı: 284, 1959.

Soysal, İlhami: "Mezhepler/Tarikatlar", Cumhuriyet Dönemi Türkiye Ansiklopedisi, Cilt: V, İletişim Yayınları, İstanbul, 1983, s. 1365-1373.

T.B.M.M. Tutanak Dergisi, C. XVI, Dönem: 8, 1949.

Tan (2 Temmuz 1940).

Tarihe Bin Canlı Tanık, "Taş taşa değmeyince duvar olmaz”, İçimizden Biri Ahmet Kaya, Milliyet-Pazar (10.8.2004).

Tasviri Efkâr (14 Haziran1941); (30 Ocak 1943).

TBMM Kavanin Mecmuası, Devre VI, İçtima: 2, 1 Teşrinisani 1941, Cilt: 22.

Toker, Metin: Tek Partiden Çok Partiye 1944-1950, Milliyet Yayınları, İstanbul, 1970 .

Tonguç, İsmail Hakkı: Canlandırılacak Köy, Remzi Kitabevi, İstanbul, 1947.

Toprak, Binnaz: “Dinci Sağ”, içinde Geçiş Sürecinde Türkiye, (Der. İrvin Cemil Schick ve E. Ahmet Tonak), Belge Yayınları, İstanbul, 1992, s. 237-254.

Tunaya, Tarık Zafer: İslamcılık Cereyanı, Baha Matbaası, İstanbul, 1962. 
Tunçay, Mete: “Tek-Parti Döneminde Basın”, Tarih ve Toplum, Cilt: VII, Sayı: 37 (Ocak 1987), s. 48-49.

Türköne, Mümtaz'er: Modernleşme, Laiklik ve Demokrasi, Ark Yayınevi, Ankara, 1994.

Uğur, Necdet: İsmet İnönü, Yapı-Kredi Yayınları, İstanbul, 1995.

Yeni Sabah (3 Ocak 1941).

Yılmaz, Mustafa: "Cumhuriyet Döneminde Bakanlar Kurulu Kararı İle Yasaklanan Yayınlar 1923-1945”, Kebikec, Y11: 3, Say1: 6, 1998, s. 53-80. 